\title{
Institutions, renewable energy consumption and industrial performance in West Africa
}

Felix Awara Eke ( $\nabla$ felix.eke@unical.edu.ng )

University of Calabar https://orcid.org/0000-0003-1915-4133

\section{Friday Bassey Agala}

University of Calabar Faculty of Social Sciences

Chukwuedo Susan Oburota

University of Calabar Faculty of Social Sciences

\section{Research}

Keywords: Institutions, Renewable Energy consumption, Industrial performance, Driscoll-Kraay standard error approach, panel-corrected standard error technique

Posted Date: September 30th, 2020

DOl: https://doi.org/10.21203/rs.3.rs-81351/v1

License: (c) (1) This work is licensed under a Creative Commons Attribution 4.0 International License.

Read Full License 
Institutions, renewable energy consumption and industrial performance in West Africa.

\title{
${ }^{* 1}$ Felix A. Eke, ${ }^{2}$ Friday B. Agala and ${ }^{3}$ Chukwuedo S. Oburota
}

\begin{abstract}
This study examined the role of institutions in modifying the impact of renewable energy consumption on industrial performance in West Africa, and how the relationship differ across countries within the sub region based on income classification. The Driscoll-Kraay standard error and the panel-corrected standard error (PCSE) techniques were utilized to estimate the fixed effects and random effects models, respectively. Institutional quality index was computed using the principal component analysis (PCA). The results reported that renewable energy consumption enhances industrial performance in West Africa and in low-income countries (LICs). However, when institutional quality is interacted with renewable energy consumption, there is a dampening impact on industrial performance not only in West Africa but also in lower-middle-income countries (LMICs). This implies that improving the quality of institutions in West Africa would be instrumental to sustaining and deepening the impact of renewable energy consumption on industrial performance.
\end{abstract}

Key words: Institutions, Renewable Energy consumption, Industrial performance, Driscoll-Kraay standard error approach, panel-corrected standard error technique JEL Classification: C33, L60, Q40.

*Correspondence: felix.eke@ unical.edu.ng, Department of Economics, Faculty of Social Sciences, PMB 1115, Calabar, Nigeria ${ }^{2}$ fridayagala1@unical.edu.ng ${ }^{3}$ susan.oburota@unical.edu.ng 


\section{Introduction}

The development and use of energy from sources such as hydropower, solar, wind, geothermal, tide and wave as well as waste and biomass are considered desirable for any economy due to its low contribution to the generation of green-house gases with corresponding minimal deleterious environmental and health effects. However, most developing economies lack the needed investments and supporting institutional framework for delivering on the quantum of renewable energy required to ginger industrial growth and development. It is in a bid to build the renewable energy infrastructure to support industrial expansion that the ECOWAS Renewable Energy Policy, adopted in July 2013 was targeted at increasing the share of renewable energy in the region's mix of total electricity generation to $23 \%$ in 2020 and to $31 \%$ in 2030 (ECREEE, 2013). This policy also sets targets for member states to institutionalize National Renewable Energy Action Plans geared towards enhancing the utilization of renewable sources of energy.

Globally, it is estimated that the renewable energy share of electricity consumption will increase from $18.3 \%$ in 2002 to $39 \%$ in 2050 while investments in renewable energy increased from $\$ 45$ billion to $\$ 270$ billion, between 2004 and 2014 (Bhattacharya, Paramati, Ozturk and Bhattacharya, 2016). This increased investment in the world notwithstanding, it is reported that the twin factors of clean energy consumption and enabling institutional arrangements necessary for economic growth and development are far from the desirable in most developing countries such as those of West Africa (Maji, Sulaiman and Abdul-Rahim, 2019). Functional institutions to promote effectiveness and enforcement of rules, efficiency in resources use as well as a smooth transition in energy use from exhaustible to renewable sources are hardly in place or are very weak to perform their statutory functions (Eke, Okoi and Eke, 2018)

Fundamentally, this study examines the role of institutions in moderating the impact of renewable energy consumption on industrial performance in the West African sub region. The motivation for this study is predicated on three points namely: the growing role of institutions in stimulating renewable energy generation as well as achieving set renewable energy targets; the importance of renewable energy in the total energy consumption mix; and the uninspiring position of West Africa in its industrialization drive vis-à-vis other sub regions in Africa and indeed, the world.

Firstly, good and effective institutions with functioning markets are pivotal to the formulation and implementation of policies that engender the attainment of energy efficiency. As noted by Kottari and Roumeliotis, (2013), for any country to achieve energy security, fostering a synergy between national institutions as well as those from the private sector and key industry players within the energy sector is sine qua non. Moreover, strong legislative framework and the rule of law together with functional market systems are prerequisites for the development of the energy sector. Evidently, policy is important for the production and consumption of renewable energy. Government policy including the policy environment plays a dynamic role in the use of renewable energy (Bhattacharya, Churchill and Paramati, 2017). Accordingly, by 2015, while 145 countries initiated renewable energy support 
policies, 164 countries had adopted their renewable energy targets (Renewables Global Status Report, 2015). These policies are not only key to renewable energy generation but also to drive industrial performance, thereby promoting economic growth.

The second motivation is based on the increasing importance of renewable energy, and the desire to reduce greenhouse effects as well as pursue energy security. The global economy has been inundated with enormous challenges arising from the significant growth and dependence on traditional sources of energy such as coal, oil and gas as nations seek to industrialize. The non-renewable nature of these sources and their contribution to the problem of greenhouse gas emission and global warming has potential to impede industrial performance (Sadorsky, 2009; Koçak and Şarkgüneşi, 2017). The recent paradigm shift towards exploring renewable sources of energy as an alternative to the traditional energy sources, thereby making renewable energy production and consumption the center piece of global and regional energy policies are designed to boost industrialization (Aniello, Többen and Kuckshinrichs, 2019). This argument underscores the preoccupation of the extant empirical inquiries into the role of renewable energy in sustaining development, which is the hallmark of industrial growth (Inglesi-Lotz, 2016; Bilgilia et al, 2019).

Thirdly, the industrial trajectories for West Africa have been abysmally weak with the sub region lagging behind other economic blocs in Africa. The industry value added as a percentage of GDP for the West Africa region for the period 2010-2018 stood at 19.34 per cent, over $10 \%$ below that of Southern African region at 29.43 per cent. In fact, the West African sub region performed below all other regions in Africa, subSaharan Africa and the average for the world (WDI, 2020) (see Table 4). The resultant effect of poor industrial growth is dwindling economic growth within the region. Statistics shows that between 2015 and 2020, the real growth rate of gross domestic product of West Africa lagged behind that of East and North Africa (African Economic Outlook, 2019) (See Table 1).

\begin{tabular}{lllllll} 
Table 1: Real GDP growth rate in & Africa by Region (2015-2020) \\
\hline Region & $\mathbf{2 0 1 5}$ & $\mathbf{2 0 1 6}$ & $\mathbf{2 0 1 7}$ & $\mathbf{2 0 1 8}$ & $\mathbf{2 0 1 9}$ & $\mathbf{2 0 2 0}$ \\
Central & 3.3 & 0.2 & 1.1 & 2.2 & 3.6 & 3.5 \\
Africa & & & & & & \\
East Africa & 6.5 & 5.1 & 5.9 & 5.7 & 5.5 & 6.1 \\
North Africa & 3.7 & 3.2 & 4.9 & 4.3 & 4.4 & 4.3 \\
Southern & 1.6 & 0.7 & 1.6 & 1.2 & 2.2 & 2.8 \\
Africa & & & & & & 3.6 \\
West Africa & $\mathbf{3 . 2}$ & $\mathbf{0 . 5}$ & $\mathbf{2 . 7}$ & $\mathbf{3 . 3}$ & $\mathbf{3 . 6}$ & $\mathbf{3 . 6}$ \\
Africa & 3.5 & 2.1 & 3.6 & 3.5 & 4.0 & 4.1
\end{tabular}

Source: African Economic Outlook, 2019

The poor industrial performance and by extension weak economic growth and development in West Africa has been attributed to a host of factors including infrastructure deficit (with poor road and transportation network, non-functional ports, inadequate power supply), non-innovative financing options (Onye, Akpama and Ikegwuonu, 2020; Effiom, 2020; Effiom and Agala, 2020), and inadequate capital 
to finance industrial expansion (Tibebe and Mollick, 2017; Asongu and Odhiambo, 2020). Having reviewed majority of the extant literature on this subject matter, we have not found to the best of our knowledge studies that $\mathrm{x}$-ray the role of institutions in modifying the impact of renewable energy consumption on industrial performance in West Africa. This study therefore charts the course in this line of scholarly investigation. The empirical considerations that are similar to this study in Africa rather focused mainly on the impact of energy consumption on industrial performance for specific countries; for instance, Nigeria (Bernard and Oludare, 2016), Tunisia (Abid and Mraihi, 2014) or on the moderating effect variables such as; capital flight (Asongu and Odhiambo, 2019), and financial development (Pradhan et al, 2018).

Some studies have also examined the nexus between institutions, renewable energy and economic performance for developed and developing countries (Bhattacharya et al, 2016), Middle East and North Africa- MENA (Saidi et al, 2019). Globally, a good number of studies focused on the relationship between renewable energy consumption and economic growth for various countries and regions e.g Black Sea and Balkan states (Koçaka, and Şarkgüneşib, 2017), Germany (Rafindadi and Ozturk, 2015; Aniello et al, 2019), United States (Bilgili et al, 2019), G-7 nations (Chang et al, 2015), OECD countries (Ohler and Fetters, 2014), Europe (Menegaki, 2010, Xie et al, 2020), Lithuania (Bobinaite et al, 2011), (Al-mulali et al, 2013) and West Africa (Maji and Abdul-Rahim, 2019).

An issue that has not received much attention in the extant literature is how institutional quality modifies the impact of renewable energy consumption on industrial performance, particularly in West Africa, a sub-region with poor industrial performance compared to other regions within sub-Sahara Africa. Also, this study makes additional contribution to the literature by analysing this relationship based on the income level of countries within the sub region i.e low-income countries (LICs) and lower-middle-income countries (LMICs) using the World Bank income classification of countries. In the light of the above arguments therefore, this study seeks to answer three basic questions in West Africa within the chosen empirical framework viz:

1. does renewable energy consumption have a positive impact on industrial performance?

2. does institutional quality modify the impact of renewable energy consumption on industrial performance?

3. does institutional quality modify the impact of renewable energy on industrial performance in LICs and LMICs equally?

The West African sub region's unpleasant history with respect to institutional quality, renewable energy consumption and industrial performance in relation to other sub-regions makes this study imperative. The outcome of this study will be relevant for policy options directed at identifying the institutional quality indices that are relevant to boost renewable energy use and foster industrial expansion. The results indicate that renewable energy consumption has not supported industrial performance despite the recent efforts to enhance its production. Moreover, weak institutions have watered down the gains from the exploration of renewable sources of energy, hence 
the minimal contribution to industrial performance. The remaining part of this paper is structured into five sections including section two that presents stylized facts on key variables. Section three discusses the methodology, and the results are reported in section four. Discussion of results and conclusion, recommendation as well as direction for future research are outlined in sections five and six, respectively.

\section{Stylized facts on Institutional quality, Renewable energy and industrial growth in West Africa}

The institutional or governance indices by the World Bank is widely used in research circles due to global acceptability and ability to capture a broad spectrum of issues pertaining to development. The World Bank decomposed institutional quality into six major indicators; Control of Corruption, Government Effectiveness, Voice and Accountability, Rule of Law, Regulatory Quality and Political Stability. In this study, we have further disaggregated the indicators into Economic Institutional index, composed of Government effectiveness and Regulatory quality; Political Institutional index is composed of Voice and Accountability and Political stability and Legal Institutional index which comprises Control of Corruption and Rule of Law.

The measures of these indices range from the weakest of -2.5 to the strongest of 2.5 and in terms of percentile rank, it ranges from the weakest of 0 to the strongest percentile of 100 (WDI, 2020).. The World Bank institutional indices are mainly sourced from the perception of respondents as well as assessment of key informants and experts in country based surveys conducted globally (WDI, 2020).

Table 2 shows the institutional quality indicators of each country within the West African sub-region divided into lower and lower middle income groups as well as the averages for each of these countries and groupings for the period 2000-2018. For the entire West Africa, Cape Verde (score of 0.92) and Ghana (0.04) had the best performance for lower middle income countries and Benin (-0.47) and Burkina Faso (-0.68) for low income countries. The countries with the worse overall institutional quality indices were; Guinea (-2.15) for low income countries and Nigeria $(-2.13)$ for lower middle income countries. The overall performance showed that low income countries (-1.35) performed worse than lower middle income countries (-0.68), and the indices for the former were also consistently lower than that of the later for all categories of institutional quality indicators. As it concerns each indicator, political institutional quality comes first for both categories of countries $(-0.94$ and -0.39 for low income and lower middle income, respectively). This is followed by legal measures ( -1.50 and -0.82 for low and lower middle income countries, respectively) and economic measures (-1.60 and -0.82 for low income and lower middle income, respectively).

Renewable energy is increasingly becoming an important source of energy for industrial activities due to the fact that it is clean, safe, sustainable and environmentally friendly. Within the sub-Saharan Africa, East Africa has the highest renewable energy consumption as percentage of total energy consumption (86.51), with Southern Africa having the least (58.38). The average for West Africa (62.55), though below the average for sub-Sahara Africa as a whole (71.17), is higher than the world average of 17.46 per cent. In the West African sub-region, the percentage 
average for low income countries (68.47) is reported to be higher than that of lowermiddle-income countries (LMICs) (50.73). Amongst the low-income countries (LICs), Guinea Bissau, Liberia and Niger have the highest renewable energy consumption of 79.11, 79.05 and 74.43 per cent, respectively. Benin, The Gambia and Togo have the lowest renewable energy consumption put at 50.37, 50.71 and 66.35, respectively. Nigeria leads the LMICs at 76.71 percent while Cape Verde is least with 24.03 per cent of renewable energy consumption (See Tables 3 and 4, respectively).

\section{Methodology}

\subsection{Principal Component Analysis (PCA)}

The PCA framework is employed in this study to group the indicators of institutional quality into a single composite index known as institutional quality index (IQ). These indicators are selected from Kuncic (2012) and Alvarez et al. (2018). The choice of the institutional quality indicators is also in tandem with the extant literature such as Zhuang, De Dios and Lagman-Martin (2010), Alvarez, et al. (2018), and Asongu and Odhiambo (2019).

The PCA approach is essential for minimizing a set of significantly correlated variables into a small set of uncorrelated indices called Principal Components (PCs). Accordingly, the PCs indicate an immense deviation of realizations from the dataset. In line with the empirical exposition of the PCA set up, common factors that reflect eigen values greater than one or the average value are to be utilized in the selection of the institutional quality index (Kaiser, 1974; Jolliffe, 2002; Asongu and Odhiambo, 2019).

This study is unique in that the indices are not only constructed for the subregion as a whole, but also for the various income classifications in West Africa. On the debate around the inferential validity of a PCA-augmented regression analysis, Asongu and Obhiambo (2019) argue that by employing the available maximum values of time (T) and cross sections $(\mathrm{N})$, inferences will be feasible and valid for a study of this magnitude. The summary of the PCA findings is reported in Table (5).

As reported in Table 5, institutional quality index (iq) represents about $80.12 \%$ of the total variations in government effectiveness, regulatory quality, control of corruption, rule of law, political stability, as well as voice and accountability for all the countries in West Africa, with an eigen value of 4.8072; while for the Lower-middle-income countries (LMICs) and the Low-income countries (LICs), institutional quality indicates about $92 \%$ and $70.78 \%$ of the information from the six indicators of institutional quality, with eigen values of 5.5201 and 4.2470 , respectively.

\subsection{Data}

Empirical analysis for the study covers the period of 2000- 2018 this is due to data constraint. Data were obtained from two sources: World Bank, World Development Indicators and African Development Bank. The variables used for estimation are described in the Table 6. Annual data of the variables were obtained for the 15 West African countries, these are Benin, Burkina Faso, Cabo Verde, Cote d'Ivoire, Ghana, Mali, Niger, Nigeria, Senegal, Sierra Leone, Guinea, Guinea - Bissau, Liberia, The Gambia and Togo. The countries in the subregion are categorized into lower-middleincome countries (LMICs) and low-income countries (LICs) based on the World 
Bank classification. LICs have per capita gross national income of $\$ 1,035$ or less while LMICs per capita income ranges from $\$ 1,036$ to $\$ 4,085$.

\subsection{Estimation Technique}

As a static panel study, and taking cognizance of the time and cross-sectional dimensions, we apply the fixed effects (FE) and random effects (RE) models in the empirical analysis. The Hausman test of 1978 is leveraged on to determine the appropriate model for analysis. The FE model can be estimated by the ordinary least squares (OLS) with panel-corrected standard errors (PCSE), feasible generalized least squares (FGLS), within fixed effects or least squares dummy variable (LSDV), the Driscoll-Kraay standard errors approach, and others. The Driscoll-Kraay (1998) technique is preferred in this study because it is a nonparametric covariance estimator that provides consistent inferential results in the presence of autocorrelation, heteroscedasticity and spatial or temporal contemporaneous correlation (Hoechle, 2007). Although the Driscoll-Kraay standard error approach presents valid and consistent outcomes, it is a slightly optimistic strategy that can generate biased estimates when the panel is unbalanced.

On the other hand, pooled ordinary least squares (POLS) or fixed-effects estimator and the generalized least squares (GLS) estimators are possible candidates for estimating the random effects model. The GLS estimator is adopted in this study because it is more suitable and efficient, especially when the explanatory variables are not correlated with the error term.

\subsection{Empirical Model}

Drawing from the extant literature reviewed, the empirical model employed in this study is presented in the form:

$\mathrm{IP}=\mathrm{f}(\mathrm{IQ}, \mathrm{REC}$, FDI, DCPS, LPOP, INFR, TO)

The panel representation of equation (1) is as follows

$$
I P_{i t}=\beta X_{i t}+\varepsilon_{i t}
$$

The error component in equation (2) is specified as

$$
\varepsilon_{i t}=\phi_{i}+\lambda_{t}+\eta_{i t}
$$

Where $\phi_{i}$ captures the unobserved country-specific effects, $\lambda_{t}$ is the unobserved time-specific effects, and $\eta_{i t}$ indicates the mutual panel effects. $X_{i t}$ in equation (2) represents the variables to be incorporated in the model. Therefore, equation (2) can be reformulated as

$$
i p_{i t}=\beta_{0}+\beta_{1} i q_{i t}+\beta_{2} r e c_{i t}+\beta_{3} f d i_{i t}+\beta_{4} d c p s_{i t}+\beta_{5} \operatorname{lpop}_{i t}+\beta_{6} \mathrm{infr}_{i t}+\beta_{7} t o_{i t}+\varepsilon_{i t}
$$

Where ip connotes industrial performance proxy by industrial value added as a share of GDP, iq indicates the composite index for institutional quality, rec is the share of renewable energy consumption to the total energy consumption mix, fdi represents the net inflow of foreign direct investment as a share of GDP, $d c p s$ is 
domestic credit to the private sector, lpop is the logarithm of population, infr is inflation rate, to denotes trade openness measured by the ratio of import and export to GDP, and $\varepsilon_{i t}$ is the error term. $\beta_{0}$ is the intercept; $\beta_{1}, \beta_{2}, \ldots, \beta_{7}$ are the coefficients of the model; $i=1,2, \ldots, 15$ for the West African subregion; $i=1,2, \ldots, 5$ for LMICs; $i=1,2, \ldots, 10$ for LICs; and $t=2000,2001, \ldots, 2018$. Although data for the institutional indicators starts from 1996, there are missing data for the countries in West Africa, especially from 1996 to 1999, hence the choice of 2000 to 2018.

In order to investigate the modifying role of institutions on renewable energy consumption vis-à-vis their impact on industrial performance in West Africa as well as the sub-categorizations, an interactive term is introduced into the model. Thus, equation (4) becomes:

$i p_{i t}=\beta_{0}+\beta_{1} i q_{i t}+\beta_{2} r e c_{i t}+\beta_{3} f d i_{i t}+\beta_{4} d c p s_{i t}+\beta_{5} \operatorname{lpop}_{i t}+\beta_{6} \mathrm{infr}_{i t}+\beta_{7} t o_{i t}+\beta_{8} i q^{*} r e c_{i t}+\varepsilon_{i t}$

5

Where $\beta_{8}$ measures the combined impact of institutional quality and renewable energy consumption on industrial performance.

\subsubsection{The Fixed Effects (FE) Model}

$I P_{i t}=\phi_{i}+x_{i t} \beta+\varepsilon_{i t}$

The FE model is driven by two basic assumptions: (i) $\phi_{i}$ are allowed to be correlated with the explanatory variables $\left(x_{i t}\right)$; (ii) there strict exogeneity, which implies that $E\left(\varepsilon_{i t} / \phi_{i}, x_{i t}\right)=0$.

This covariance model takes into account unobserved time-invariant components of the cross sections; and thus, consistent estimates of the marginal impact of the regressors on industrial performance are obtained. The inclusion of $\phi_{i}$ in the model is relevant when controlling for differences between cross-sectional units, while variance across units is constant. $\beta$ represents a vector of coefficients, $x_{i t}$ is a vector of regressors, and $\varepsilon_{i t}$ is the disturbance term.

\subsubsection{The Random Effects (RE) Model}

$I P_{i t}=x_{i t} \beta+u_{i t}$ for $\mathrm{i}=1, \ldots, \mathrm{N} ; \mathrm{t}=1, \ldots, \mathrm{T}$

This error components approach is based on the assumptions of: (i) $\phi_{i}$ are uncorrelated with $x_{i t}$, and (ii) there is strict exogeneity. 
Where $u_{i t}=\phi_{i}+\varepsilon_{i t} ; \phi_{i}$ represents between sections error, and $\phi_{i}:$ i.i.d $\left(\phi, \sigma_{\phi}^{2}\right)$; $\varepsilon_{i t}$ is within sections error, and $\varepsilon_{i t}:$ i.i.d $\left(0, \sigma^{2}\right)$. This indicates that country specific effects $\phi_{i}$ are identically and independently distributed of $x_{i t}$. The estimates of the error variances unique to cross sections are essential for capturing individual heterogeneity. Therefore, $\phi_{i}$ are considered to be a component of the composite disturbance term, hence differences among cross sections are obtained from their country-specific error term instead of the individual intercepts

\section{Results}

\subsection{Descriptive statistics}

The descriptive statistics is reported in Table 7. The average value of industrial performance for the subregion is 19.34; while the mean values for LMICs and LICs are 23.167 and 17.424 , respectively.

Table 7: Descriptive Statistics

\begin{tabular}{llllll}
\hline \multicolumn{5}{l}{ For all the Countries (LMICs and LICs) in West African subregion } \\
Variable (s) & Mean & Std. Dev. & Minimum & Maximum & Observations \\
\hline IP & 19.339 & 6.733 & 3.243 & 34.85 & 285 \\
IQ & -0.575 & 2.192 & -4.985 & 5.169 & 285 \\
REC & 62.555 & 27.626 & 0.000 & 91.510 & 285 \\
FDI & 4.970 & 10.817 & -1.032 & 103.337 & 285 \\
DCPS & 15.655 & 12.680 & 0.000 & 65.741 & 285 \\
LPOP & 15.921 & 1.328 & 12.967 & 19.093 & 285 \\
INFR & 5.660 & 6.336 & -3.507 & 34.702 & 285 \\
TO & 69.606 & 34.601 & 21.074 & 297.305 & 285 \\
For Lower-Middle-Income Countries (LMICs) in West African subregion & \\
\hline IP & 23.167 & 3.972 & 16.903 & 34.859 & 95 \\
IQ & 0.733 & 2.349 & -4.039 & 3.564 & 95 \\
REC & 50.727 & 26.726 & 0.000 & 88.83 & 95 \\
FDI & 3.480 & 2.870 & 0.502 & 12.666 & 95 \\
DCPS & 23.189 & 16.069 & 8.084 & 65.741 & 95 \\
LPOP & 16.419 & 1.885 & 12.967 & 19.092 & 95 \\
INFR & 6.619 & 7.082 & -2.4 & 32.9 & 95 \\
TO & 72.579 & 22.563 & 21.074 & 117.265 & 95 \\
For Low-Income & Countries & $($ LICs) in West African subregion & \\
\hline IP & 17.424 & 7.016 & 3.243 & 34.275 & 190 \\
IQ & 0.679 & 2.060 & -5.518 & 4.074 & 190 \\
REC & 68.468 & 26.193 & 0.000 & 91.51 & 190 \\
FDI & 5.715 & 13.040 & -1.032 & 103.337 & 190 \\
DCPS & 5.715 & 8.357 & 0.000 & 41.156 & 189 \\
LPOP & 15.671 & 0.834 & 13.998 & 16.926 & 190 \\
INFR & 5.180 & 5.890 & -3.507 & 34.702 & 190 \\
TO & 68.119 & 39.232 & 28.132 & 297.305 & \\
\hline
\end{tabular}

(Note: IP, IQ, REC, FDI, DCPS, LPOP, INFR and TO are as described in Table 6)

Source: Computed by authors, 2020.

The industrial performance standard deviation ranges from 3.50 to 7.02 , with the LMICs having the least value of 3.97. The minimum value of industry's share to GDP is 3.24 for LICs and for all the countries in West Africa, with LMICs having the 
highest value of 16.90. The industry's share could rise up to 34.86. Institutional quality for all the countries and income classifications averaged between -0.575 and 0.733 , with variation from 2.060 to 2.349 . The lowest value for institutional quality is -5.518 and could increase to 5.196 over time. Economic institutions index has mean values of $-0.180,0.208$, and -0.182 for all the countries, LMICs, and LICs, respectively. The standard deviation ranges from 1.358 to 1.368 . the least economic institutions index is -3.471 and has potential to peak at 2.875. Legal institutions index average value ranges from -0.305 to 0.706 , with LMICs having the highest standard deviation of 1.396. The minimum values are $-2.987,-2.292$, and -3.434 for all the countries, LMICs and LICs, respectively. The index could assume a maximum value of 3.670. The average values for political institutions index are between -0.237 and 0.278 . It varies from 1.197 to 1.383 . LICs have the least minimum value of -3.626 , and the maximum value ranges from 2.106 to 2.847 . Renewable energy consumption as share of overall energy consumption on the average is 62.555 for all the countries, 50.727 for LMICs, and 68.468 for LICs. The standard deviation lies between 26.193 and 27.626. For all the categories, the minimum share of REC to GDP is 0.1 , and the share could increase to 91.510 . FDI net inflow as share of GDP averaged between 3.480 and 5.715; it varies significantly from 2.870 to 13.040 , and it could reach the maximum value of 103.337. Domestic credit to the private sector as percentage of GDP has a mean value of 15.655 for West Africa, 23.189 for LMICs, and 5.715 for LICs. The LICs have the least variation with a value of 8.357. The minimum share of DCPS is 0 and could peak at 65.741. The average values of the logarithm of population are 69.606, 72.519, and 68.119 for West Africa, LMICs, and LICs, respectively. LPOP varies widely from 22.563 to 39.232 . The least value is 21.074 , and could rise to 297.035. Inflation rates averaged 5.660, 6.619, and 5.180, respectively for West Africa, LMICs, and LICs. The standard deviation varies from 5.890 to 7.082 . INFR could increase from -3.507 to 34.702 . More so, trade openness average value ranges from 68.119 to 72.519 , with high level of variation between 22.563 and 39.232. From 21.074, TO could attain a maximum value of 297.305 in the sub region.

\subsection{Results for West Africa countries}

The results reported in Table 8 show that the Wald test values of 48.75, 47.83, 65.01, and 42.75, as well as the F-test statistics of 10.22, 10.27, 12.60, and 8.98 indicate the presence of entity effects that are not captured in the panel, and there exists unique features among the countries in West Africa. The null hypothesis of no omitted variables is thus rejected; and we report that the panel contains omitted variables. This report makes the estimates of the fixed and random effects models to be preferred over the pooled OLS estimates. The Hausman test statistics of 11.58, 11.30, 12.36, and 12.23 for both models are insignificant. This implies that we fail to reject the null hypothesis of the appropriateness of the generalized least squares (GLS) estimates, and confirm that the random effects (RE) models are preferred to the fixed effects (FE) models. Table 9 reports the estimates of the RE models for all the countries in West Africa. The results indicate that there is a positive but insignificant relationship between institutional quality and industrial performance in the West African 
subregion. Renewable energy consumption is also found to be positively but insignificantly related to the outcome variable. 
Table 8: Institution and Renewable Energy Consumption and Industrial

Performance in West Africa

\begin{tabular}{|c|c|c|c|c|}
\hline & \multicolumn{4}{|c|}{ Random Effects (re) Models } \\
\hline & Model I & Model II & Model III & Model IV \\
\hline \multicolumn{5}{|l|}{ DV: IP } \\
\hline IQ & $\begin{array}{l}0.2938 \\
(0.2809)\end{array}$ & & & \\
\hline \multirow[t]{2}{*}{ REC } & 0.0058 & 0.0052 & 0.0062 & 0.0057 \\
\hline & $(0.0099)$ & $(0.0103)$ & $(0.0099)$ & $(0.0094)$ \\
\hline \multirow[t]{2}{*}{ FDI } & $0.0154 * *$ & $0.0165 * *$ & $0.0149 * *$ & $0.0153 * *$ \\
\hline & $(0.0063)$ & $(0.0065)$ & $(0.0064)$ & $(0.0061)$ \\
\hline \multirow[t]{2}{*}{ DCPS } & -0.0539 & -0.0495 & -0.0562 & -0.0544 \\
\hline & $(0.0494)$ & $(0.0498)$ & $(0.0502)$ & $(0.0493)$ \\
\hline \multirow[t]{2}{*}{ LPOP } & $2.2542 * *$ & $2.1469 * *$ & $2.2978 * *$ & $2.2087 *$ \\
\hline & (1.0589) & $(1.0347)$ & $(1.0273)$ & (1.1413) \\
\hline \multirow[t]{2}{*}{ INFR } & -0.0285 & -0.0273 & -0.0288 & -0.0299 \\
\hline & $(0.0800)$ & $(0.0780)$ & $(0.0793)$ & $(0.0803)$ \\
\hline \multirow[t]{2}{*}{ TO } & 0.0055 & 0.0060 & 0.0047 & 0.0050 \\
\hline & $(0.0119)$ & $(0.0116)$ & $(0.0124)$ & $(0.0121)$ \\
\hline Const. & -16.372 & -14.742 & -16.996 & -15.593 \\
\hline Adj. $R^{2}$ & 0.693 & 0.698 & 0.684 & 0.694 \\
\hline W-Test & 48.75 & 47.83 & 65.01 & 42.75 \\
\hline \{Prob.\} & $\{0.000\}$ & $\{0.000\}$ & $\{0.000\}$ & $\{0.000\}$ \\
\hline H-Test & 11.58 & 11.3 & 12.36 & 12.23 \\
\hline$\{$ Prob. $\}$ & $\{0.115\}$ & $\{0.126\}$ & $\{0.189\}$ & $\{0.193\}$ \\
\hline
\end{tabular}

Notes: $* * *, * *$, and $*$ denote $1 \%, 5 \%$, and $10 \%$ levels of significance.

W-Test represents the Wald test, H-Test depicts the Hausman test, \{\} is for the probability values, and ( ) is for the standard errors.

Source: Computed by authors, 2020

Foreign direct investment (FDI) and the logarithm of population (LPOP) have a positive and significant impact on industrial value added. On the average, across time and between countries, $1 \%$ increase in the net inflow of FDI to the industrial sector leads to about $0.016 \%$ boost in industrial performance, especially in the presence of strong economic institutions. More so, while domestic credit to the private sector (DCPS) and inflation rates (INFR) influence industrial performance negatively but insignificantly, trade openness exerts positive but insignificant impact on the growth of the industrial sector.

The interaction between renewable energy consumption (REC) and institutions to drive industrial performance in West Africa is reported in Table 9. Based on the results of the Wald test, F-test statistics and the Hausman test reported in Table 11, the RE models are again considered to be more appropriate for analysis. The results presented in Table 4 show that when renewable energy consumption is interacted with institutions, institutions and REC have negative and significant impacts on industrial performance in the subregion. Particularly, the adverse effects of institutions on industrial value-added share to gross domestic product are more profound when REC is interacted with the legal and political institutions. The average effects of legal and political institutions over industrial performance across time and between countries is -0.019. Again, FDI and LPOP impact positively on industrial performance in West Africa. 


\subsection{Lower middle income countries}

The Wald test values are $84.15,81.17,83.36$, and 88.05, respectively; and the F-test statistics are $6.74,6.61,7.63$, and 8.14 depict the presence of entity effects that are not captured in the panel, and there are specific features among Lower-Middle-Income countries (LMICs).The null hypothesis of no omitted variables is thus rejected; and we report that the panel contains omitted variables. This report makes the estimates of the fixed and random effects models to be preferred over the pooled OLS estimates. The Hausman test statistics of 14.18, 14.99, 14.08, and 12.39 for both models are significant at 5\% and $10 \%$, respectively. This implies that we reject the null hypothesis of the appropriateness of the generalized least squares (GLS) estimates, and confirm that the fixed effects (FE) models are preferred to the random effects (RE) models. The diagnostic tests for the FE models presented in table 10 are conducted to determine whether the models exhibit the problems of contemporaneous correlation, heteroscedasticity, or autocorrelation that could lead to biased FE estimates. (See Table 10)

As reported in Table 10, there is a contemporaneous correlation among the sampled countries; and the series exhibit the problems of non-constant variance and first-order serial correlation. To correct for the presence of cross-sectional dependence, heteroscedasticity and autocorrelation, we employed the Driscoll-Kraay Standard Errors Analysis to estimate the fixed effects models. These results are reported in Table 11. As shown in the same table, institutions have positive and significant impact on industrial performance in Lower-Middle-Income countries (LMICs) in West Africa. Political institutions are found to play greater role in promoting the growth of industrial value added. The results indicate that a unit improvement in political institutions (PI) will cause industrial performance to increase by 1.196. REC for countries in the lower-middle-income categorization has adverse impact on the industrial sector. The reports also show that the net inflow of FDI and DCPS are negatively and significantly related to industrial performance, while population and trade openness facilitate industrial drive in LMICs.

The Wald test values in Table 12, shows that are 93.79, 90.05, 91.36, and 96.51, respectively; and the F-test statistics are 3.65, 3.42, 3.59, and 3.61. These two tests report the presence of entity effects that are not captured in the panel, and there are heterogeneous features among Lower-Middle-Income countries (LMICs). The null hypothesis of no omitted variables is thus rejected; and we report that the panel contains omitted variables. This report makes the estimates of the fixed and random effects models to be preferred over the pooled OLS estimates. The Hausman test statistics of $11.83,12.16,12.86$, and 10.10 for both models are insignificant. This implies that we fail to reject the null hypothesis of the appropriateness of the generalized least squares (GLS) estimates, and thus confirm that the random effects (RE) models are preferred to the fixed effects (FE) models. Table 11 contains the estimates of the RE models for LMICs. 
Table 12: Renewable Energy Consumption and Industrial Performance via Institutions in LMICs

\begin{tabular}{|c|c|c|c|c|}
\hline \multicolumn{5}{|c|}{ Random Effects (re) Models } \\
\hline & Model I & Model II & Model III & Model IV \\
\hline \multicolumn{5}{|l|}{ DV: IP } \\
\hline IQ & $\begin{array}{l}1.6653 * * * \\
(0.5702)\end{array}$ & & & \\
\hline REC & $\begin{array}{l}-0.0501 * * * \\
(0.0179)\end{array}$ & $\begin{array}{l}-0.0522 * * * \\
(0.0176)\end{array}$ & $\begin{array}{l}-0.0525 * * * \\
(0.0182)\end{array}$ & $\begin{array}{l}-0.0447 * * \\
(0.0179)\end{array}$ \\
\hline FDI & $\begin{array}{l}-0.2142 \\
(0.1601)\end{array}$ & $\begin{array}{l}-0.1635 \\
(0.1578)\end{array}$ & $\begin{array}{l}-0.2036 \\
(0.1613)\end{array}$ & $\begin{array}{l}-0.2323 \\
(0.1594)\end{array}$ \\
\hline DCPS & $\begin{array}{l}-0.0865 * * \\
(0.0413)\end{array}$ & $\begin{array}{l}-0.0655^{*} * \\
(0.0405)\end{array}$ & $\begin{array}{l}-0.1051 * * \\
(0.0439)\end{array}$ & $\begin{array}{l}-0.0897 * * \\
(0.0411)\end{array}$ \\
\hline LPOP & $\begin{array}{l}2.4770 * * * \\
(0.5625)\end{array}$ & $\begin{array}{l}2.1861 * * * \\
(0.5347)\end{array}$ & $\begin{array}{l}2.5630^{* * * *} \\
(0.5865)\end{array}$ & $\begin{array}{l}2.5273 * * * \\
(0.5505)\end{array}$ \\
\hline INFR & $\begin{array}{l}0.0161 \\
(0.0600)\end{array}$ & $\begin{array}{l}0.0434 \\
(0.0596)\end{array}$ & $\begin{array}{l}0.0096 \\
(0.0604)\end{array}$ & $\begin{array}{l}0.0052 \\
(0.0596)\end{array}$ \\
\hline TO & $\begin{array}{l}0.0845 * * * \\
(0.0270)\end{array}$ & $\begin{array}{l}0.0769 * * * \\
(0.0265)\end{array}$ & $\begin{array}{l}0.0861 \text { *** } \\
(0.0274)\end{array}$ & $\begin{array}{l}0.0874 \\
(0.0270)\end{array}$ \\
\hline $\mathrm{IQ}^{*} \mathrm{REC}$ & $\begin{array}{l}-0.0181 * * \\
(0.0078)\end{array}$ & & & \\
\hline EI*REC & & $\begin{array}{l}-0.0283 * * \\
(0.0125)\end{array}$ & & \\
\hline $\mathrm{LI}^{*} \mathrm{REC}$ & & & $\begin{array}{l}-0.0304 * * \\
(0.0142)\end{array}$ & \\
\hline PI*REC & & & & $\begin{array}{l}-0.0278 * * \\
(0.0128)\end{array}$ \\
\hline Const. & $-19.223^{*}$ & -14.496 & $-20.199 *$ & $-20.255^{*}$ \\
\hline Adj. $\mathrm{R}^{2}$ & 0.522 & 0.512 & 0.515 & 0.529 \\
\hline W-Test & 93.79 & 90.05 & 91.36 & 96.51 \\
\hline$\{$ Prob. $\}$ & $\{0.000\}$ & $\{0.000\}$ & $\{0.000\}$ & $\{0.000\}$ \\
\hline H-Test & 11.83 & 12.16 & 12.86 & 10.10 \\
\hline$\{$ Prob. $\}$ & $\{0.159\}$ & $\{0.144\}$ & $\{0.116\}$ & $\{0.258\}$ \\
\hline
\end{tabular}

Notes: $* * *, * *$, and $*$ denote $1 \%, 5 \%$, and $10 \%$ levels of significance. W-Test represents the Wald test, H-Test depicts the Hausman test, \{\} is for the probability values, and ( ) is for the standard errors.

Source: Computed by authors, 2020

The results indicate that institutions exert positive and significant impact on industrial performance in LMICs with the legal institutions having the greatest impact on industrial value added. This implies that a unit increase in the quality of legal institutions in LMICs will lead to 2.914 growth in industrial performance on the average, across time and between countries. However, when the consumption of renewable energy is interacted with institutions, their combined impact on industrial performance is negative and significant.

\subsection{Low income countries}

The Wald test estimates of 66.07, 71.11, 80.12, and 60.21, as well as the F-test statistics of $10.65,11.09,10.81$, and 11.06 are reported in Table 13. These results depict the presence of entity effects that are not captured in the panel, and there exists unique features among the Low-Income Countries (LICs). The null hypothesis of no omitted variables is thus rejected; and we report that the panel contains omitted variables. This report makes the estimates of the fixed and random effects models to be preferred over the pooled OLS estimates. The Hausman test statistics of 2.79, 2.49, 
4.75, and 2.64 for both models are insignificant. This implies that we fail to reject the null hypothesis of the appropriateness of the generalized least squares (GLS) estimates, and confirm that the random effects (RE) models are preferred to the fixed effects (FE) models. The results are reported in Table 8. The results show that there is a positive but insignificant relationship between institutional quality and industrial performance in the LICs. Renewable energy consumption and the net inflow of FDI are found to be positively and significantly related to the outcome variable. On the average, across time and between entities, a 1\% increase in REC will enhance industrial performance by $0.015 \%$.

Furthermore, the reports of the Wald test values of 91.33, 96.40, 87.49, and 101.69, respectively; and the F-test statistics are 4.06, 12.03, 6.05, and 3.97 are presented in Table 14. These two tests report the presence of entity effects that are not captured in the panel, and there are unique features among LICs. The null hypothesis of no omitted variables is thus rejected; and we report that the panel contains omitted variables. This report makes the estimates of the fixed and random effects models to be preferred over the pooled OLS estimates. The Hausman test statistics of 4.06, $12.03,6.05$, and 3.97 for both models are insignificant. This implies that we fail to reject the null hypothesis of the appropriateness of the generalized least squares (GLS) estimates, and thus confirm that the random effects (RE) models are preferred to the fixed effects (FE) models. The estimates of the RE models for LICs are reported in Table 14. The results indicate that only economic institutions impact positively on industrial performance in LICs albeit insignificantly when institutions are interacted with renewable energy consumption.

\section{Discussion of results}

This study set out to investigate the role of institutional quality in enhancing the impact of renewable energy consumption on industrial performance in West Africa, and if this differs with the country's level of income in accordance with the world Bank income classification. The results indicate that in West Africa renewable energy consumption does not trigger industrial performance. This implies that majority of renewable energy harnessed in West Africa is not channeled to the industry that needs it. The outcome is quite revealing considering the fact that the contribution of renewable energy to the total energy consumption mix is estimated to be 62.55 percent in West Africa as against that of Southern Africa estimated at 58.38 per cent for the period studied. This occurs because there is greater consumption of nonrenewable energy sources such as coal or oil and gas; besides, these exhaustible energy sources are mostly used to power industries in the sub region. This result is contrary to the reports of Adewuyi and Awodumi (2016) for Nigeria, Balgili (2015) and Hoang (2020) for the United States which found that renewable energy contributes positively to industrial growth in those countries, but these studies were narrowed to specific countries. Findings from this study also reveal that there is a positive but insignificant relationship between institutional quality and industrial performance in the West Africa. This shows that institutions within the sub region are weak. Political instability, corruption and weak governance framework are chronic problems confronting West African countries. 
The interaction of institutions with renewable energy consumption does not improve industrial performance in West Africa. Poor institutional quality significantly dampens the positive effect of renewable energy on industrial performance. This can be attributed to political instability, terrorism and utter disregard for the rule of law in countries within the region. Also, corruption and lack of political will among leaders within the sub region greatly hampers the development of various renewable energy options which could be harnessed for the benefit of the industrial sector. In Nigeria for instance, corruption and lack of political will to promote rule of law and enforce contracts has impeded the development of the energy sector (and other critical infrastructure) with detrimental effect on the country's industrial performance (Ubi and Udah, 2019). This is also the case in other leading West African countries such as Ghana (Werlin, 1973; Forson, 2015; Abokyi et al, 2018), Ivory Coast (Sharma, 2102) and Senegal (Sall, 2105).

Foreign direct investment plays an important role in enhancing industrial performance and this is in agreement with the study in Africa by Adegboye et al (2016). However, this can be more beneficial with effective economic, legal and political institutions. Population growth significantly impacts industrial value added because it offers needed manpower and large markets for industrial outputs. Domestic credit to the private sector did not significantly impact industrial growth. This is because financial institution were unable to transfer deposits as credit to the private sector in order to boost industrial performance but rather prefer short term lending to lucrative sector such as trade and petroleum services. Trade openness had no impact on industrial value added because regional trade among member states and with other trading partners is very low. Trade among member states within the sub region can be considered unfair by all standards as they basically export raw materials and intermediate products while they import finished goods from other parts of the world. The export share to other West African countries by Ghana and Nigeria is estimated at a meager 8.5 percent (Uexkull, 2012), while the major trading partners for countries within the sub region are Europe, the BRICS nations and China (Torres and van Seters, 2016). Liberalization of trade should be encouraged among countries in the LICs because this will ensure free movement of factors of production needed in the industrial sector and invariably increase output within the sub region. The adverse relationship between inflation and industrial performance implies that a steady rise in the average price of products in West African countries would reduce industrial output. Foreign direct investments in LICs promote industrial performance, but the impact has been rather marginal; this is probably because a significant portion of the net inflows of FDI is directed to extractive industry (Ismail, 2012). There is therefore the need to encourage the countries to channel more FDI to the industrial sector as this would trigger investment and ultimately increase the quantity of goods and services produced.

In lower-middle-income countries (LMICs), renewable energy use has an adverse effect on industrial performance. This is supported by the evidence of low utilization of renewable energy in the LMICs, which is put at about 51 per cent on the average when compared to that of LICs $(68.5 \%)$. This may not be unconnected with LMICs 
dependence on oil and gas for their energy consumption needs which greatly reduces their reliance on renewable energy sources. Also, institutions play an important role in boosting industrial performance in LMICs. This could be attributed to the presence of better institutional indicators on the average when compared with LICs. This finding is supported by evidence from studies such as Shenaz, et al. (2018) and Grigorian and Martines (2000). More so, domestic credit to the private sector does not stimulate industrial performance in LMICs. This is due to economic and political uncertainties and unwillingness on the part of financial institutions to fund industrial activities. Also, renewable energy consumption and institutions exert a negative but significant impact on industrial performance. Hence, the interaction between renewable energy and institutions does not enhance industrial performance in the LMICs. This occurs because despite the positive effect of institutions on industrial performance, the level of renewable energy consumption among LMICs is very low, thus institutional quality is unable to enhance the capacity of renewable energy to propel industrialization in LMICs. Thus, the negative effect of renewable energy consumption in these countries erodes the benefits of the positive impact of institutions on industrial performance.

In the LICs, renewable energy consumption has a positive impact on industrial value added because there is a high dependency on biomass and other sources of renewable energy for production purposes in these countries. In the LICs, institutional quality does not improve industrial performance despite having positive relationship with industrial value added. This is largely because the quality of institutions in these countries is still predominantly weak as it is evident in their poor average score (1.35). In lower-income countries, the interaction of renewable energy consumption and institutions has a positive but insignificant relationship with industrial performance. This implies that though institutions have potential to enhance industrial performance, they are relatively weak in LICs.

\section{Conclusion, recommendations and directions for future research}

This study investigated whether the impact of renewable energy consumption on industrial performance is modified by institutional quality, and whether this is true for low- and lower-middle-income countries in West Africa. The study focused on fifteen West African countries of which ten (Benin, Burkina Faso, Mali, Niger, Sierra Leone, Guinea, Guinea - Bissau, Liberia, The Gambia and Togo) are low income, and five (Cabo Verde, Cote d'Ivoire, Ghana, Nigeria, Senegal) are lower middle income countries for the period 2000-2018. The fixed effects and random effects models were estimated by the Driscoll-Kraay standard error approach and the generalized least square technique, respectively. The principal component analysis (PCA) was utilized for bundling institutional quality into a single composite index. Three research questions were asked which include: (i) does renewable energy have a positive impact on industrial performance? (ii) does institutional quality modify the impact of renewable energy consumption on industrial performance? (iii) does institutional quality modify the impact of renewable energy consumption on industrial performance in low- and lower-middle-income countries equally? The study established that: question one was answered in the affirmative for the whole of West 
Africa and for low income countries in the sub region, but disproved for lowermiddle-income countries. Question two was answered in the affirmative for lowincome countries, while this cannot be said to be the case for LMICs and the sub region as a whole. The answer for the third question reveals that institutional quality modifies the impact of renewable energy consumption in the LICs and West African sub region.

The industrial growth potentials of West African countries is not in contention, however this should be complemented by strong political will and enabling institutional arrangements (to deal with corruption and enforce rule of law) as well as policies to boost renewable energy generation and consumption especially for LMICs. Enhancing industrial performance within the sub region requires that the quality of institutions are enhanced to strengthen policy framework for improved energy utilization especially from clean, safe and sustainable renewable sources. Besides these policy implications, this study has thus contributed to the extant literature as it has shown that indeed institutional quality modulates the impact of renewable energy consumption on industrial performance in West Africa, and that countries income level is important in this relationship.

This area of scholarly inquiry offers rich research opportunities for further studies, especially in extending this current investigation to other sub-regional economic blocs within Africa, as well as a comparative analysis between the African region and other regions of the world. This would be essential to ascertain whether there are lessons to learn from the industrial experiences of other global economic groupings. Also the role of institutions in industrialization while considering the economic blocs within West Africa i.e West Africa Monetary Zone (WAMZ) and West Africa Monetary Union (WAEMU) can be explored.

Acknowledgements: The authors are very grateful to the Editor and Reviewers for their invaluable comments.

Authors' contributions: FAE, FBA and CSO conceptualized the idea, contributed various sections in the writing of the manuscript and FBA undertook the data analysis. FAE, FBA and CSO participated in the revision of the manuscript, as well as reading and approval of the final manuscript.

Funding: The authors have received no funding.

Availability of data and materials: The data is available upon request.

Ethics approval and consent to participate: Not applicable.

Consent for publication: Not applicable.

Competing interests: The authors declare that they have no competing interests. 


\section{References}

Abid, M. and Mraihi, R. (2014). "Energy consumption and industrial production: evidence from Tunisia at both aggregated and disaggregated levels". J Knowl Econ. Springer Science+Business Media New York. https://doi.org/10.1007/s13132-014-0190-y

Abokyi, E., Appiah-Konadu, P., Sikayena, I., F. Oteng-Abayie, E.

(2018). "Consumption of electricity and industrial growth in the case of Ghana". Journal of Energy. https://doi.org/10.1155/2018/8924835

Awodumi, O. B., and Adewuyi, A. O. (2017). "Biomass energy consumption, economic growth and carbon emission: Fresh evidence from West Africa using a Simultaneous Equation modelling". Energy, vol. 119, issue C: 453471.

\section{https://doi.org/10.1016/j.energy.2016.12.059}

African Development Bank. 2019. "Macroeconomic performance and prospects. Jobs, growth and firm dynamism. Integration for Africa's economic prosperity". African Economic Outlook. www.afdb.org

Al-mulali, U., Fereidouni, H. G., Lee, J. Y. and Sab, C. N. (2013).

"Examining the bi-directional long run relationship between renewable energy consumption and GDP growth". Renewable and Sustainable Energy

Reviews, 22: 209-222. https://doi.org/10.1016/j.rser.2013.02.005

Àlvarez, I. C., Barbero, J., Rodriguez-Pose, A. and Zofìo, J. L. (2018). Does Institutional Quality Matter for Trade? Institutional Conditions in a Sectoral Trade Framework. World Development,103:72-87. https://doi.org/10.1016/j.worlddev.2017.10.010.

Aniello, W., Többen, J. and Kuckshinrichs, W. (2019). The Transition to Renewable Energy Technologies-Impact on Economic Performance of North Rhine- Westphalia. Applied Sciences, 9:111 https://doi.org/10.3390/app9183783

Asongu, S. A. and Nwachukwu, J. (2016). Revolution empirics: predicting the Arab Spring. Empirical Economics, Springer, 51(2): 439-482, September. https://doi.org/10.1007/s00181-015-1013-0

Asongu, S.A. and Odhiambo, N. M. (2019a). Governance, capital flight and industrialisation in Africa. Economic Structures (2019) 8(36): 1-22 https://doi.org/10.1186/s40008-019-0170-2

Asongu, S. A. and Odhiambo, N. M. (2019b). Governance and social media in African countries: An empirical investigation. Telecommunications Policy, Elsevier, 43(5): 411-425. https://doi.org/10.1016/j.telpol.2018.10.004. 
Asongu, S. A. and Nnanna, J. (2019). Foreign aid, instability and governance in Africa. Politics and Policy 47(4):807-848 https://doi.org/10.1111/polp.12320

Asongu, S. A. and Odhiambo, N. M. (2020). Remittances, the diffusion of information and industrialisation in Africa. Contemporary Social Science. https://doi.org/10.1080/21582041.2019.1618898

Bernard, O. A. and Oludare, A. (2016). Is energy consumption relevant to industrial output in Nigeria? European Journal of Research in Social Sciences, 4(4): 1-14.

Bhattacharya, M., Paramati, S. R., Ozturk, I., \& Bhattacharya, S. (2016). The effect of renewable energy consumption on economic growth: Evidence from top 38 countries. Applied Energy, 162: 733-741.

Bhattacharya M., Awaworyi C. and Paramati S. (2017). The dynamic impact of renewable energy and institutions on economic output and $\mathrm{CO} 2$ emissions across regions, Renewable

Energy. https://doi.org/10.1016/j.renene.2017.03.102.

Bilgilia, F., Kuşkayab, S., Toğuçc, N., Muğaloğlud, E., Koçaka, E., Bulute, U. and Bağlitaş, H. (2019). "A revisited renewable consumption-growth nexus: A continuous wavelet approach through disaggregated data". Renewable and Sustainable Energy Reviews 100: 1-19. https://doi.org/10.1016/j.rser.2019.02.017

Bobinaite, V., Juozapaviciene, A. and Konstantinaviciute, I. (2011).

Assessment of Causality Relationship between Renewable Energy Consumption and Economic Growth in Lithuania. Inzinerine EkonomikaEngineering Economics, 22(5), 510-518. https://doi.org/10.5755/j01.ee.22.5.969

Chang, T., Gupta, R., Inglesi-Lotz, R., Simo-Kengne, B., Smithers, D. and Trembling, A. (2015). Renewable energy and growth: evidence from a heterogeneous panel of G7 countries using Granger causality. Renewable Sustainable Energy Review 52: 1405-1412. http://dx.doi.org/10.1016/j.rser.2015.08.022

Driscoll, J. C. and Kraay, A. C. (1998). Consistent Covariance Matrix Estimation with Spatially Dependent Panel Data. The Review of Economics and Statistics, 80(4): 549-560. www.jstor.org/stable/2646837

ECREEE. 2013. ECOWAS Renewable Energy Policy. ECOWAS Centre for Renewable Energy and Energy Efficiency, Cabo Verde. www.ecreee.org Effiom, L. and Agala, F. B. (2020). Infrastructure and Africa's

Development: The Imperative of Alternative Funding Options in D. Seck (ed.), Financing Africa's Development, Advances in African Economic, Social and Political Development. Springer Nature Switzerland, 53-71. https://doi.org/10.1007/978-3-030-46482-0_4 
Effiom, L. (2020). Transport and ICT Infrastructure Development in the ECOWAS Sub-Region: The PPP Funding Alternative in D. Seck (ed.), Financing Africa's Development, Advances in African Economic, Social and Political Development. Springer Nature Switzerland, https://doi.org/10.1007/978-3-030-46482-0_4

Eke, F., Okoi, O. B. and Eke, I. (2018). Institutional Quality, Energy Consumption Mix and Industrial Sustainability in Nigeria. African Journal of Applied and Theoretical Economics. 4 (1):73-94.

Forson, J. A. (2015). Corruption, EU Aid inflows and Economic Growth in

Ghana: Cointegration and Causality. Contemporary Economics, 9(3), 299318.

Hausman, J. A. (1978). Specification Tests in Econometrics. Econometrica, 46, 12511271.

Hoang, Thi Hong Van, Syed Jawad Hussain Shahzad and Robert L. Czudaj.

(2020). "Renewable energy consumption and industrial production: A disaggregated time-frequency analysis for the U.S.” Energy Economics, 85. https://doi.org/10.1016/j.eneco.2019.06.018

Hoechle, D. (2007). Robust Standard Errors for Panel Regressions with Crosssectional

Dependence. The Stata Journal, 7(3), 281-312.

Inglesi-Lotz, R. (2016). The impact of renewable energy consumption to economic growth: a panel data application. Energy Economics 53, 58-63.

Ismail, N. (2012). FDI- A Blessing or a Curse for West Africa. Global Policy Forum.

New York, USA. www.globalpolicy.org

Jolliffe, H. F. (2002). Principal Component Analysis. Second edition, Springer-Verlag New York, Secaucus, NJ.

Koçaka, E. and Şarkgüneşi, A. (2017). The renewable energy and economic growth nexus in black sea and Balkan Countries. Energy Policy 100: 54-57. https://doi.org/10.1016/j.enpol.2016.10.007

Kottari, M. and Roumeliotis, P. (2013). Renewable energy governance challenges within a "puzzled" institutional map In Renewable energy governance; complexities and challenges (eds) Michalena, Evanthie, and Jeremy Maxwell Hills. Springer-Verlag London. 233-248 https://doi.org/10.1007/978-1-4471-5595-9_14

Kuncic, A. (2012). Institutional Quality Database. Kiel Advanced Studies Working Papers, No. 457, Kiel Institute for the World Economy. http://hdl.handle.net/10419/57941

Kaiser, H. F. (1974). An Index of Factorial Simplicity. Psychometrika, 39, 31-36. https://doi.org/10.1007/BF02291575

Maji, I., Sulaiman, C. and Abdul-Rahim, A. (2019). Renewable energy consumption and economic growth nexus: A fresh evidence from West Africa. Energy Reports 5: 384-392. https://doi.org/10.1016/j.egyr.2019.03.005

Menegaki, A. N. (2011). Growth and renewable energy in Europe: a 
random effect model with evidence for neutrality hypothesis. Energy Economics33:257-63 http://dx.doi.org/10.1016/j.eneco.2010.10.004

Ohler, A. and Fetters, I. (2014). The causal relationship between renewable electricity generation and GDP growth: a study of energy sources. Energy Economics 43, 125-39. http://dx.doi.org/10.1016/j.eneco.2014.02.009

Onye, K., Akpama, O. and Ikegwuonu, A. (2020). Infrastructure Development in West Africa: What Is the Role of Concessionary External Debt? in Financing Africa's Development, Advances in African Economic, Social and Political Development. ed. D. Seck 53-71. Springer Nature Switzerland. https://doi.org/10.1007/978-3-030-46482-0_4

Pradhan, R. P., Arvin, M., Nair, M., Bennett, S. and Hall, J. (2018). The dynamics between energy consumption patterns, financial sector development and economic growth in Financial Action Task Force (FATF) Countries, Energy. https://doi.org/10.1016/j.energy.2018.06.094

Rafindadi, A.A. and Ozturk, I. (2017). Impacts of renewable energy consumption

on the German economic growth: Evidence from combined cointegration test. Renewable and Sustainable Energy Reviews 75:1130-1141. http://dx.doi.org/10.1016/j.rser.2016.11.093

REN21. (2015). Renewables. Global status report. REN21: France.

Sadorsky, P. (2009). Renewable energy consumption and income in emerging economies. Energy Policy 37, 4021-4028.

Saidi, H., El Montasser, G. and Ajmi, N. (2019). The role of institutions in the Renewable Energy-Growth nexus in the MENA region: a Panel Cointegration Approach. Environmental Modeling and Assessment https://doi.org/10.1007/s10666-019-09672-y

Sall, I. (2015). Trust in Political Institutions in Senegal: Why did it drop?

Afrobameter Policy Paper, No. 24.

Sharma, M. (2012). Does good governance influence economic development?

Examples from Ghana and Ivory Coast. The Indian Journal of Political science, 73(4), 729-744. https://doi.org/10.2307/41858880

Tibebe, T. and Mollick, A. (2017). Financial development and economic growth in Africa. Journal of African Business. 18(3):320-339

Torres C. and van Seters J. (2016). Overview of trade and barriers to trade in West Africa: insights in political economy dynamics with particular focus on agriculture and food trade. European center for Development and policy management. No 195.

Ubi, P. and Udah, E. (2019). Impact of Governance and Road Infrastructure on Industrial Growth in Nigeria. Nigerian Journal of Economic and Social Studies, 61 (1): 123-154

von Uexkull, E. (2012). 'Regional Trade and Employment in ECOWAS', in Policy Priorities for International Trade and Jobs, ed. D. Lippoldt 7193-236. OECD e-publication, www.oecd.org/trade/icite. 415-446. 
Werlin, H. H. (1973). The consequences of corruption: The Ghanaian experience. The Academy of Political science, 88(1), 71-85. https://doi.org/10.2307/2148649.

World Bank. (2017). World Development Indicators. Retrieved from http://www.worldbank.org

World Bank. (2020). World Development Indicators. Retrieved from http://www.worldbank.org

Xie, Fangming, Yali Liu, Fangyuan Guan and Ning Wang. (2020). "How to coordinate the relationship between renewable energy consumption and green economic development: from the perspective of technological advancement". Environmental Sciences Europe. 32:71.

https://doi.org/10.1186/s12302-020-00350-5

Zhuang, Juzhong, Emmanuel de Dios, and Anneli Lagman-Martin. (2010).

Governance and Institutional Quality and Links with Economic Growth and Income Inequality: with Special Reference to Developing Asia. $A D B$ Economics Working Paper Series, No. 193, Asian Development Bank. www.adb.org/economics 


\section{Appendices}

Appendix 1: See Table 3

Table 3: Renewable energy consumption in West Africa 2010-2016

\begin{tabular}{|c|c|c|c|c|c|c|c|c|}
\hline Country & 2010 & 2011 & 2012 & 2013 & 2014 & 2015 & 2016 & $\begin{array}{l}2000-2016 \\
*\end{array}$ \\
\hline \multicolumn{9}{|c|}{ Low Income } \\
\hline Benin & 48.1 & 49.5 & 51.2 & 52.7 & 52.5 & 50.8 & 49.9 & 50.37 \\
\hline Burkina Faso & 81.45 & 80.57 & 77.18 & 75.43 & 75.24 & 72.71 & 72.26 & 71.96 \\
\hline The Gambia & 54.71 & 54.16 & 54.22 & 56.64 & 51.93 & 51.51 & 51.33 & 50.71 \\
\hline Guinea & 75.71 & 74.75 & 76.37 & 78.53 & 78.52 & 76.27 & 75.11 & 71.54 \\
\hline Guinea Bissau & 87.81 & 87.72 & 87.61 & 87.42 & 87.06 & 86.85 & 86.45 & 79.11 \\
\hline Liberia & 89.21 & 87.37 & 85.18 & 86.99 & 83.94 & 83.85 & 82.91 & 79.05 \\
\hline Mali & 69.13 & 66.65 & 64.93 & 62.41 & 64.59 & 61.53 & 59.43 & 67.05 \\
\hline Niger & 80.71 & 77.27 & 72.75 & 78.74 & 78.15 & 78.94 & 79.69 & 74.43 \\
\hline Sierra Lone & 84.18 & 80.35 & 78.43 & 75.22 & 73.05 & 77.66 & 77.63 & 74.13 \\
\hline Togo & 65.83 & 69.16 & 72.74 & 72.40 & 72.16 & 71.26 & 71.63 & 66.35 \\
\hline Average & 73.68 & 72.74 & 72.05 & 72.65 & 71.72 & 71.14 & 70.64 & 68.47 \\
\hline \multicolumn{9}{|c|}{ Lower-middle income } \\
\hline Cape Verde & 21.74 & 21.62 & 24.40 & 26.13 & 26.20 & 26.58 & 25.23 & 24.03 \\
\hline Cote d'Ivoire & 75.37 & 78.90 & 74.90 & 72.58 & 72.22 & 64.53 & 62.66 & 64.11 \\
\hline Ghana & 49.78 & 48.01 & 44.48 & 44.04 & 45.05 & 41.41 & 41.96 & 48.87 \\
\hline Nigeria & 86.78 & 86.15 & 86.45 & 86.78 & 87.30 & 86.64 & 82.40 & 76.71 \\
\hline Senegal & 50.26 & 48.66 & 50.37 & 43.59 & 43.36 & 42.71 & 37.58 & 39.91 \\
\hline Average & 56.79 & 56.67 & 56.12 & 54.63 & 54.83 & 52.37 & 49.97 & 50.73 \\
\hline West Africa & 68.05 & 67.38 & 66.74 & 66.64 & 66.09 & 64.89 & 63.75 & 62.55 \\
\hline East Africa & 89.94 & 89.12 & 88.58 & 78.17 & 77.79 & 77.5 & 78.14 & 86.51 \\
\hline Southern Africa & 58.72 & 58.2 & 57.28 & 56.7 & 56.51 & 56.28 & 56.31 & 58.38 \\
\hline Sub-Sahara Africa & 70.94 & 71.42 & 71.08 & 70.31 & 70.04 & 70.28 & 70.12 & 71.17 \\
\hline World & 17.51 & 17.26 & 17.21 & 17.48 & 17.70 & 17.87 & 18.05 & 17.46 \\
\hline
\end{tabular}


Appendix 2: See Table 4

Table 4: Share of industrial output to GDP in West Africa and regions in Africa

\begin{tabular}{|c|c|c|c|c|c|c|c|c|c|c|}
\hline Country & 2010 & 2011 & 2012 & 2013 & 2014 & 2015 & 2016 & 2017 & 2018 & $\begin{array}{l}2000- \\
2018 \\
\end{array}$ \\
\hline & \multicolumn{10}{|c|}{ Low Income } \\
\hline $\begin{array}{l}\text { Benin } \\
\text { Burkina }\end{array}$ & 22.14 & 21.59 & 20.16 & 20.84 & 20.77 & 20.64 & 20.13 & 21.54 & 21.48 & 23.94 \\
\hline $\begin{array}{l}\text { Faso } \\
\text { The }\end{array}$ & 21.02 & 24.70 & 22.37 & 18.76 & 19.80 & 18.99 & 19.53 & 20.69 & 19.45 & 18.98 \\
\hline Gambia & 9.83 & 11.52 & 11.96 & 11.89 & 13.21 & 17.14 & 20.93 & 17.89 & 15.56 & 13.6 \\
\hline Guinea & 32.31 & 32.61 & 31.58 & 29.64 & 29.69 & 26.32 & 30.10 & 31.65 & 24.81 & 30.94 \\
\hline $\begin{array}{l}\text { Guinea } \\
\text { Bissau }\end{array}$ & 13.14 & 12.40 & 13.54 & 14.42 & 14.42 & 12.25 & 12.55 & 12.60 & 12.63 & \\
\hline Liberia & 4.99 & 8.30 & 16.39 & 15.76 & 15.71 & 12.54 & 7.98 & 10.19 & 12.51 & 8.57 \\
\hline Mali & 22.73 & 20.65 & 19.87 & 18.62 & 18.38 & 17.59 & 17.17 & 18.11 & 19.11 & 21.2 \\
\hline Niger & 15.62 & 15.94 & 21.07 & 21.62 & 19.38 & 17.69 & 16.97 & 15.86 & 15.48 & 16.55 \\
\hline $\begin{array}{l}\text { Sierra } \\
\text { Leone }\end{array}$ & 7.78 & 7.87 & 14.53 & 21.23 & 15.61 & 4.56 & 5.611 & 5.16 & 5.27 & 10.47 \\
\hline Togo & 14.98 & 17.13 & 18.40 & 17.63 & 16.17 & 15.59 & 16.94 & 15.33 & 15.46 & 16.07 \\
\hline Average & 16.45 & 17.27 & 18.98 & 19.04 & 18.32 & 16.33 & 16.79 & 16.91 & 16.18 & 17.42 \\
\hline \multicolumn{11}{|c|}{ Lower-middle income } \\
\hline $\begin{array}{l}\text { Cape Verde } \\
\text { Cote }\end{array}$ & 18.15 & 17.76 & 17.00 & 17.51 & 18.72 & 18.12 & 17.13 & 18.19 & 19.18 & 18.51 \\
\hline d'Ivoire & 22.41 & 24.20 & 24.02 & 25.95 & 27.41 & 25.78 & 25.23 & 24.69 & 25.24 & 23.73 \\
\hline Ghana & 18.01 & 23.86 & 27.13 & 34.86 & 34.59 & 31.68 & 28.23 & 30.78 & 31.53 & 25.73 \\
\hline Nigeria & 25.32 & 28.28 & 27.07 & 25.74 & 24.64 & 20.16 & 18.17 & 22.32 & 25.74 & 25.33 \\
\hline Senegal & 21.56 & 23.09 & 22.79 & 24.09 & 23.15 & 23.59 & 23.34 & 25.75 & 25.83 & 22.54 \\
\hline $\begin{array}{l}\text { Average } \\
\text { West }\end{array}$ & 21.08 & 22.44 & 23.61 & 25.63 & 25.71 & 23.86 & 22.42 & 24.35 & 25.51 & 23.17 \\
\hline Africa & 17.99 & 19.32 & 20.52 & 21.23 & 20.77 & 18.84 & 18.66 & 19.38 & 19.28 & 19.34 \\
\hline $\begin{array}{l}\text { East Africa } \\
\text { Southern }\end{array}$ & 23.5 & 26.5 & 24.97 & 19.85 & 23.73 & 23.1 & 18.4 & 17.82 & 17.5 & 21.82 \\
\hline $\begin{array}{l}\text { Africa } \\
\text { sub-Sahara }\end{array}$ & 32.1 & 30.84 & 30.4 & 29.7 & 29.6 & 29.7 & 28.33 & 28.59 & 28.7 & 29.43 \\
\hline Africa & 27.98 & 29.31 & 27.79 & 27.13 & 26.56 & 24.54 & 24.24 & 25.33 & 24.91 & 26.42 \\
\hline World & 27.19 & 27.38 & 26.97 & 26.60 & 26.38 & 25.55 & 25.12 & 25.44 & NA & 26.33 \\
\hline
\end{tabular}

Source: Computed by authors with data from WDI, 2020 
Appendix 3: See Table 5

Table 5: Principal Component Analysis for Composite Institutional Quality Indices For all the Countries (LMICs and LICs) in West African subregion

\begin{tabular}{|c|c|c|c|c|c|c|c|c|c|}
\hline \multirow{2}{*}{$\begin{array}{l}\text { Principal } \\
\text { Component }\end{array}$} & \multicolumn{6}{|c|}{ Component Matrix (Loadings) } & \multirow{2}{*}{$\begin{array}{l}\text { Proportion } \\
(\%)\end{array}$} & \multirow{2}{*}{$\begin{array}{l}\text { Cumulative } \\
\text { Proportion }\end{array}$} & \multirow{2}{*}{$\begin{array}{l}\text { Eigen } \\
\text { Value }\end{array}$} \\
\hline & GE & RQ & $\mathrm{COC}$ & ROL & PS & VAA & & & \\
\hline $1^{\text {st }} \mathrm{PC}$ (iq) & 0.423 & 0.406 & 0.426 & 0.445 & 0.351 & 0.389 & 80.12 & 0.8012 & 4.8072 \\
\hline $2^{\text {nd }} P C$ & $\begin{array}{l}- \\
0.348\end{array}$ & $\begin{array}{l}- \\
0.359\end{array}$ & $\begin{array}{l}- \\
0.117\end{array}$ & $\begin{array}{l}- \\
0.025\end{array}$ & 0.843 & 0.151 & 8.38 & 0.8850 & 0.5030 \\
\hline $1^{\mathrm{st}} \mathrm{PC}(\mathrm{ei})$ & 0.707 & & & & & & 93.49 & 0.9349 & 1.8699 \\
\hline $2^{\text {nd }} P C$ & 0.707 & $-\overline{0.707}$ & & & & & 6.51 & 1.0000 & 0.1301 \\
\hline $1^{\text {st }} \mathrm{PC}$ (li) & & & 0.707 & & & & 95.66 & 0.9566 & 1.9132 \\
\hline $2^{\text {nd }} P C$ & & & 0.707 & - & & & 4.34 & 1.0000 & 0.0867 \\
\hline $1^{\mathrm{st}} \mathrm{PC}(\mathrm{pi})$ & & & & & 0.707 & & 81.07 & 0.8107 & 1.6215 \\
\hline $2^{\text {nd }} \mathrm{PC}$ & & & & & 0.707 & - & 18.93 & 1.0000 & 0.3785 \\
\hline
\end{tabular}

For Lower-Middle-Income Countries (LMICs) in West African subregion

\begin{tabular}{|c|c|c|c|c|c|c|c|c|c|}
\hline $1^{\text {st }} \mathrm{PC}$ (iq) & 0.414 & 0.382 & 0.409 & 0.420 & 0.413 & 0.409 & 92 & 0.9200 & 5.5201 \\
\hline $2^{\text {nd }} P C$ & 0.069 & 0.876 & $\begin{array}{l}- \\
0.327\end{array}$ & $\begin{array}{l}- \\
0.113\end{array}$ & $\begin{array}{l}- \\
0.155\end{array}$ & $\begin{array}{l}- \\
0.288\end{array}$ & 4.09 & 0.9610 & 0.2456 \\
\hline $1^{\mathrm{st}} \mathrm{PC}(\mathrm{ei})$ & 0.707 & & & & & & 93.64 & 0.9364 & 1.8728 \\
\hline $2^{\text {nd }} P C$ & 0.707 & $\begin{array}{l}- \\
0.707\end{array}$ & & & & & 6.39 & 1.0000 & 0.1271 \\
\hline $1^{\text {st }} \mathrm{PC}$ (li) & & & 0.707 & & & & 97.54 & 0.9754 & 1.9508 \\
\hline $2^{\text {nd }} P C$ & & & 0.707 & $\begin{array}{l}- \\
0.707\end{array}$ & & & 2.46 & 1.0000 & 0.0491 \\
\hline $1^{\mathrm{st}} \mathrm{PC}(\mathrm{pi})$ & & & & & 0.707 & & 95.71 & 0.9571 & 1.9142 \\
\hline $2^{\text {nd }} P C$ & & & & & 0.707 & $\begin{array}{l}- \\
0.707\end{array}$ & 4.29 & 1.0000 & 0.0857 \\
\hline
\end{tabular}

For Low-Income Countries (LICs) in West African subregion

\begin{tabular}{|c|c|c|c|c|c|c|c|c|c|}
\hline $1^{\text {st }} \mathrm{PC}$ (iq) & 0.433 & 0.446 & 0.431 & 0.462 & 0.318 & 0.332 & 70.78 & 0.7078 & 4.2470 \\
\hline $2^{\text {nd }} P C$ & - & - & - & - & 0.758 & 0.422 & 11.91 & 0.8269 & 0.7144 \\
\hline $1^{\text {st }} \mathrm{PC}$ (ei) & $\begin{array}{l}0.314 \\
0.707\end{array}$ & 0.214 & 0.317 & 0.028 & & & 92.28 & 0.9228 & 1.8456 \\
\hline $2^{\text {nd }} P C$ & 0.707 & $\begin{array}{l}- \\
0.707\end{array}$ & & & & & 7.72 & 1.0000 & 0.1543 \\
\hline $1^{\text {st }} \mathrm{PC}$ (li) & & & 0.707 & & & & 91.79 & 0.9179 & 1.8357 \\
\hline $2^{\text {nd }} P C$ & & & 0.707 & $\begin{array}{l}- \\
0.707\end{array}$ & & & 8.21 & 1.0000 & 0.1642 \\
\hline $1^{\mathrm{st}} \mathrm{PC}(\mathrm{pi})$ & & & & & 0.707 & & 71.70 & 0.7170 & 1.4339 \\
\hline $2^{\text {nd }} P C$ & & & & & 0.707 & $\begin{array}{l}- \\
0.707\end{array}$ & 28.30 & 1.0000 & 0.5660 \\
\hline
\end{tabular}

Notes: PC is the Principal Component, GE is government effectiveness, RQ represents regulatory quality, COC is the control of corruption, ROL connotes the rule of law, PS is political stability, VAA is voice and accountability, IQ (a composite index for institutional quality) is the first PC of GE, RQ, COC, ROL, PS, and VAA.

Source: Computed by authors, 2020 
Appendix 4: See Table 6

Table 6: Summary of Variable Description and Sources

\begin{tabular}{|c|c|c|}
\hline Variable & Description & Source \\
\hline $\begin{array}{l}\text { Control of } \\
\text { Corruption (COC) }\end{array}$ & $\begin{array}{l}\text { Control of Corruption captures perceptions of the extent to which } \\
\text { public power is exercised for private gain, including both petty } \\
\text { and grand forms of corruption, as well as "capture" of the state by } \\
\text { elites and private interests }\end{array}$ & $\begin{array}{l}\text { http://dataportal.opendataf } \\
\text { orafrica.org/nbyenxf/afdb- } \\
\text { socio-economic-database }\end{array}$ \\
\hline $\begin{array}{l}\text { Government } \\
\text { Effectiveness (GE) }\end{array}$ & $\begin{array}{l}\text { Government Effectiveness refers to the perceptions of the quality } \\
\text { of public services, the quality of the civil service and the degree } \\
\text { of its independence from political pressures, the quality of policy } \\
\text { formulation and implementation, and the reliability of the } \\
\text { government's obligation to such policies. }\end{array}$ & $\begin{array}{l}\text { http://dataportal.opendataf } \\
\text { orafrica.org/nbyenxf/afdb- } \\
\text { socio-economic-database }\end{array}$ \\
\hline $\begin{array}{l}\text { Political Stability } \\
\text { and Absence of } \\
\text { Violence/Terrorism } \\
\text { (PS) }\end{array}$ & $\begin{array}{l}\text { Political Stability and Absence of Violence/Terrorism measures } \\
\text { perceptions of the likelihood of political instability and/or } \\
\text { politically-motivated violence, including terrorism. }\end{array}$ & $\begin{array}{l}\text { http://dataportal.opendataf } \\
\text { orafrica.org/nbyenxf/afdb- } \\
\text { socio-economic-database }\end{array}$ \\
\hline $\begin{array}{l}\text { Regulatory Quality } \\
\text { (RQ) }\end{array}$ & $\begin{array}{l}\text { Regulatory Quality refers to the perceptions of the ability of the } \\
\text { government to formulate and implement sound policies and } \\
\text { regulations that permit and promote private sector development. }\end{array}$ & $\begin{array}{l}\text { http://dataportal.opendataf } \\
\text { orafrica.org/nbyenxf/afdb- } \\
\text { socio-economic-database }\end{array}$ \\
\hline $\begin{array}{l}\text { Rule of Law } \\
\text { (ROL) }\end{array}$ & $\begin{array}{l}\text { Rule of Law reflects the degree to which agents have confidence } \\
\text { in and abide by the rules of society, and in particular the quality of } \\
\text { contract enforcement, property rights, the police, and the courts, } \\
\text { as well as the likelihood of crime and violence. }\end{array}$ & $\begin{array}{l}\text { http://dataportal.opendataf } \\
\text { orafrica.org/nbyenxf/afdb- } \\
\text { socio-economic-database }\end{array}$ \\
\hline $\begin{array}{l}\text { Voice and } \\
\text { Accountability } \\
\text { (VAA) }\end{array}$ & $\begin{array}{l}\text { voice and Accountability refers to the degree to which a country's } \\
\text { citizens are able to participate in selecting their government, as } \\
\text { well as freedom of expression, freedom of association, and a free } \\
\text { media }\end{array}$ & $\begin{array}{l}\text { http://dataportal.opendataf } \\
\text { orafrica.org/nbyenxf/afdb- } \\
\text { socio-economic-database }\end{array}$ \\
\hline $\begin{array}{l}\text { Institutional } \\
\text { Quality index } \\
\text { (IQ) }\end{array}$ & $\begin{array}{l}\text { Computed from the various indicators of institutional quality } \\
\text { employing the principal component analysis (PCA). }\end{array}$ & $\begin{array}{l}\text { https://data.worldbank.org/ } \\
\text { indicator/ }\end{array}$ \\
\hline $\begin{array}{l}\text { Foreign Direct } \\
\text { Investment net } \\
\text { inflow (\% of GDP) } \\
\text { (FDI) }\end{array}$ & $\begin{array}{l}\text { This is value of investment made by non-resident investors in the } \\
\text { reporting economy, including reinvested earnings and intra- } \\
\text { company loans, net of repatriation of capital and repayment of } \\
\text { loans. Unit of measurement percentage }\end{array}$ & $\begin{array}{l}\text { https://data.worldbank.org/ } \\
\text { indicator/ }\end{array}$ \\
\hline $\begin{array}{l}\text { Domestic Credit to } \\
\text { the private sector } \\
\text { (DCPS) }\end{array}$ & $\begin{array}{l}\text { This refers to financial resources provided to the private sector by } \\
\text { financial institutions. }\end{array}$ & $\begin{array}{l}\text { https://data.worldbank.org/ } \\
\text { indicator/ }\end{array}$ \\
\hline Population (POP) & Total population of the country & $\begin{array}{l}\text { https://data.worldbank.org/ } \\
\text { indicator/ }\end{array}$ \\
\hline $\begin{array}{l}\text { Inflation, consumer } \\
\text { prices (annual \%) } \\
\text { (INFR) }\end{array}$ & $\begin{array}{l}\text { Inflation as measured by the consumer price index reflects the } \\
\text { annual percentage change in the cost to the average consumer of } \\
\text { acquiring goods and services }\end{array}$ & $\begin{array}{l}\text { http://dataportal.opendataf } \\
\text { orafrica.org/nbyenxf/afdb- } \\
\text { socio-economic-database }\end{array}$ \\
\hline $\begin{array}{l}\text { Industry, value } \\
\text { added (\% of GDP) } \\
\text { (IP) }\end{array}$ & $\begin{array}{l}\text { It comprises the value added in mining, manufacturing, } \\
\text { construction, electricity, water and gas. value added is the net } \\
\text { output of the industry after adding up all outputs and subtracting } \\
\text { intermediate inputs. }\end{array}$ & $\begin{array}{l}\text { https://data.worldbank.org/ } \\
\text { indicator/ }\end{array}$ \\
\hline $\begin{array}{l}\text { Renewable energy } \\
\text { share in the total } \\
\text { final energy } \\
\text { consumption }(\%) \\
\text { (REC) }\end{array}$ & $\begin{array}{l}\text { The renewable energy share in total final consumption is the } \\
\text { percentage of final consumption of energy that is derived from } \\
\text { renewable resources. }\end{array}$ & $\begin{array}{l}\text { http://dataportal.opendataf } \\
\text { orafrica.org/nbyenxf/afdb- } \\
\text { socio-economic-database } \\
\text { https://data.worldbank.org/ } \\
\text { indicator/ }\end{array}$ \\
\hline $\begin{array}{l}\text { Total Trade ( as \% } \\
\text { of GDP) (TO) }\end{array}$ & $\begin{array}{l}\text { This comprises a country's export and import as a share of the } \\
\text { GDP }\end{array}$ & $\begin{array}{l}\text { http://dataportal.opendataf } \\
\text { orafrica.org/nbyenxf/afdb- } \\
\text { socio-economic-database }\end{array}$ \\
\hline
\end{tabular}

Source: Computed by authors from literature review, 2020 
Appendix 5: See Table 9

Table 9: Renewable Energy Consumption and Industrial Performance in West

Africa via institutions

\begin{tabular}{|c|c|c|c|c|}
\hline & \multicolumn{4}{|c|}{ Random Effects (re) Models } \\
\hline & Model I & Model II & Model III & Model IV \\
\hline \multicolumn{5}{|l|}{ DV: IP } \\
\hline IQ & $\begin{array}{l}1.3308 \text { *** } \\
(0.4116)\end{array}$ & & & \\
\hline \multirow[t]{2}{*}{ REC } & -0.0020 & -0.0013 & 0.0030 & 0.0007 \\
\hline & $(0.0093)$ & $(0.0099)$ & $(0.0101)$ & $(0.0010)$ \\
\hline \multirow[t]{2}{*}{ FDI } & $0.0162 * *$ & $0.0156 * *$ & $0.0159 * *$ & $0.0187 * * *$ \\
\hline & $(0.0071)$ & $(0.0078)$ & $(0.0068)$ & $(0.0069)$ \\
\hline \multirow[t]{2}{*}{ DCPS } & -0.0794 & -0.0614 & -0.0831 & -0.0747 \\
\hline & $(0.0532)$ & $(0.0525)$ & $(0.0571)$ & $(0.0498)$ \\
\hline \multirow[t]{2}{*}{ LPOP } & $2.4511 * *$ & $2.1792 * *$ & $2.5223 * *$ & $2.3634 * *$ \\
\hline & $(1.0439)$ & $(1.0101)$ & $(1.0162)$ & $(1.1664)$ \\
\hline \multirow[t]{2}{*}{ INFR } & -0.0187 & -0.0127 & -0.0237 & -0.0301 \\
\hline & $(0.0780)$ & $(0.0724)$ & $(0.0779)$ & $(0.0804)$ \\
\hline \multirow[t]{2}{*}{ TO } & 0.0046 & 0.0045 & 0.0043 & 0.0052 \\
\hline & $(0.0114)$ & $(0.0113)$ & $(0.0121)$ & $(0.0112)$ \\
\hline \multirow[t]{2}{*}{ IQ*REC } & $-0.0136^{* *}$ & & & \\
\hline & $(0.0060)$ & & & \\
\hline \multirow[t]{2}{*}{ EI*REC } & & -0.0152 & & \\
\hline & & $(0.0107)$ & & \\
\hline \multirow[t]{2}{*}{ LI*REC } & & & $-0.0196 * *$ & \\
\hline & & & $(0.0096)$ & \\
\hline \multirow[t]{2}{*}{ PI*REC } & & & & $-0.0198^{*}$ \\
\hline & & & & $(0.0109)$ \\
\hline Const. & -18.98 & -14.86 & -20.082 & -17.728 \\
\hline Adj. $\mathbf{R}^{2}$ & 0.729 & 0.732 & 0.715 & 0.718 \\
\hline W-Test & 59.74 & 72.65 & 70.44 & 45.7 \\
\hline$\{$ Prob. $\}$ & $\{0.000\}$ & $\{0.000\}$ & $\{0.000\}$ & $\{0.000\}$ \\
\hline H-Test & 8.56 & 8.69 & 9.94 & 10.42 \\
\hline$\{$ Prob. $\}$ & $\{0.285\}$ & $\{0.275\}$ & $\{0.269\}$ & $\{0.236\}$ \\
\hline
\end{tabular}

Notes: ***,**, and * denote $1 \%, 5 \%$, and $10 \%$ levels of significance. W-Test represents

the Wald test, H-Test depicts the Hausman test, \{\} is for the probability values, and ( ) is for the standard errors.

Source: Computed by authors, 2020

Appendix 6: See Table 10

Table 10: Diagnostic Tests for the Fixed Effects Models

\begin{tabular}{|c|c|c|c|c|c|c|c|c|}
\hline \multirow[b]{2}{*}{ Estimated Models } & \multicolumn{4}{|c|}{ Statistics } & \multicolumn{4}{|c|}{ Probability } \\
\hline & $\begin{array}{l}\text { Model } \\
\text { I }\end{array}$ & $\begin{array}{l}\text { Model } \\
\text { II }\end{array}$ & $\begin{array}{l}\text { Model } \\
\text { III }\end{array}$ & $\begin{array}{c}\text { Model } \\
\text { IV }\end{array}$ & $\begin{array}{l}\text { Model } \\
\text { I }\end{array}$ & $\begin{array}{l}\text { Model } \\
\text { II }\end{array}$ & $\begin{array}{l}\text { Model } \\
\text { III }\end{array}$ & $\begin{array}{c}\text { Model } \\
\text { IV }\end{array}$ \\
\hline $\begin{array}{l}\text { Breusch-Pagan (CD) } \\
\text { Test }\end{array}$ & 23.499 & 27.684 & 23.47 & 21.743 & $\{0.009\}$ & $\{0.002\}$ & $\{0.009\}$ & $\{0.016\}$ \\
\hline $\begin{array}{l}\text { Heteroscedasticity } \\
\text { (Wald Test) }\end{array}$ & 309.85 & 296.16 & 277.68 & 309.41 & $\{0.000\}$ & $\{0.000\}$ & $\{0.000\}$ & $\{0.000\}$ \\
\hline $\begin{array}{l}\text { Autocorrelation } \\
\text { (Wooldrige-Test) }\end{array}$ & 69.233 & 67.57 & 70.06 & 70.723 & $\{0.001\}$ & $\{0.001\}$ & $\{0.001\}$ & $\{0.001\}$ \\
\hline
\end{tabular}

Source: Computed by authors, 2020 
Appendix 7: See Table 11

Table 11: Institutions, Renewable Energy Consumption and Industrial Performance in Lower-Middle-Income Countries (LMICs) in West Africa

\begin{tabular}{|c|c|c|c|c|}
\hline & \multicolumn{4}{|c|}{ Fixed Effects (fe) Models } \\
\hline & Model I & Model II & Model III & Model IV \\
\hline \multicolumn{5}{|l|}{ DV: IP } \\
\hline \multirow{2}{*}{ IQ } & $0.6254 * *$ & & & \\
\hline & $(0.2585)$ & & & \\
\hline \multirow[t]{2}{*}{ REC } & -0.0022 & -0.0040 & -0.0044 & -0.0025 \\
\hline & $(0.0135)$ & $(0.0134)$ & $(0.0138)$ & $(0.0132)$ \\
\hline \multirow[t]{2}{*}{ FDI } & $-0.3919 * *$ & $-0.3828 * *$ & $-0.3830 * *$ & $-0.3859 * *$ \\
\hline & $(0.1787)$ & $(0.1800)$ & $(0.1793)$ & $(0.1788)$ \\
\hline \multirow[t]{2}{*}{ DCPS } & $-0.1593 * * *$ & $-0.1512 * * *$ & $-0.1595 * *$ & $-0.1559 * * *$ \\
\hline & $(0.0479)$ & $(0.0487)$ & $(0.0485)$ & $(0.0438)$ \\
\hline \multirow[t]{2}{*}{ LPOP } & $14.4996 * * *$ & $14.6496 * * *$ & $14.1668 * * *$ & $13.5864 * * *$ \\
\hline & $(4.5675)$ & $(4.7235)$ & $(4.7501)$ & $(4.3601)$ \\
\hline \multirow[t]{2}{*}{ INFR } & -0.0664 & -0.0676 & -0.0708 & -0.0552 \\
\hline & $(0.1144)$ & $(0.1163)$ & $(0.1175)$ & $(0.1077)$ \\
\hline \multirow[t]{2}{*}{ TO } & $0.1324 * * *$ & $0.1327 * * *$ & $0.1322 * * *$ & $0.1258 * * *$ \\
\hline & $(0.0328)$ & $(0.0332)$ & $(0.0329)$ & $(0.0320)$ \\
\hline Const. & $-218.91 * *$ & $-221.51 * *$ & $-213.31 * *$ & $-203.5 * *$ \\
\hline Adj. $R^{2}$ & 0.235 & 0.228 & 0.23 & 0.237 \\
\hline F-Test & 6.74 & 6.61 & 7.63 & 8.14 \\
\hline$\{$ Prob. $\}$ & $\{0.000\}$ & $\{0.000\}$ & $\{0.000\}$ & $\{0.000\}$ \\
\hline H-Test & 14.18 & 14.99 & 14.08 & 12.39 \\
\hline$\{$ Prob. $\}$ & $\{0.048\}$ & $\{0.036\}$ & $\{0.049\}$ & $\{0.088\}$ \\
\hline
\end{tabular}

Notes: $* * *, * *$, and $*$ denote $1 \%, 5 \%$, and $10 \%$ levels of significance. W-Test represents the Wald test, H-Test depicts the Hausman test, \{\} is for the probability values, and ( ) is for the standard errors.

Source: Computed by authors, 2020 
Appendix 8: See Table 13

Table 13: Institutions, Renewable Energy Consumption and Industrial Performance in LICs

\begin{tabular}{|c|c|c|c|c|}
\hline & \multicolumn{4}{|c|}{ Random Effects (re) Models } \\
\hline & Model I & Model II & Model III & Model IV \\
\hline \multicolumn{5}{|l|}{ DV: IP } \\
\hline IQ & $\begin{array}{l}0.1367 \\
(0.3431)\end{array}$ & & & \\
\hline \multirow[t]{2}{*}{ REC } & $0.0148 *$ & $0.0142 *$ & $0.0157 * *$ & $0.0143 *$ \\
\hline & $(0.0077)$ & $(0.0078)$ & $(0.0077)$ & $(0.0076)$ \\
\hline \multirow[t]{2}{*}{ FDI } & $0.0222 * * *$ & $0.0232 * * *$ & $0.0211^{* * *}$ & $0.0230 * * *$ \\
\hline & $(0.0047)$ & $(0.0040)$ & $(0.0044)$ & $(0.0057)$ \\
\hline \multirow[t]{2}{*}{ DCPS } & -0.0620 & -0.0592 & -0.0646 & -0.0608 \\
\hline & $(0.0926)$ & $(0.0929)$ & $(0.0928)$ & $(0.0929)$ \\
\hline \multirow[t]{2}{*}{ LPOP } & 1.8053 & 1.5825 & 2.0383 & 1.5654 \\
\hline & $(2.6629)$ & $(2.5930)$ & $(2.4300)$ & $(2.8320)$ \\
\hline \multirow[t]{2}{*}{ INFR } & -0.0189 & -0.0182 & -0.0184 & -0.0208 \\
\hline & $(0.1005)$ & $(0.0994)$ & $(0.1013)$ & $(0.0950)$ \\
\hline \multirow[t]{2}{*}{ TO } & 0.0014 & 0.0018 & 0.0007 & 0.0013 \\
\hline & $(0.0090)$ & $(0.0085)$ & $(0.0097)$ & $(0.0095)$ \\
\hline Const. & -11.276 & -7.812 & -14.906 & -7.478 \\
\hline Adj. $\mathrm{R}^{2}$ & 0.829 & 0.843 & 0.808 & 0.842 \\
\hline W-Test & 66.07 & 71.11 & 80.12 & 60.21 \\
\hline$\{$ Prob. $\}$ & $\{0.000\}$ & $\{0.000\}$ & $\{0.000\}$ & $\{0.000\}$ \\
\hline H-Test & 2.79 & 2.49 & 4.75 & 2.64 \\
\hline$\{$ Prob. $\}$ & $\{0.903\}$ & $\{0.927\}$ & $\{0.690\}$ & $\{0.916\}$ \\
\hline
\end{tabular}

Notes: $* * *, * *$, and $*$ denote $1 \%, 5 \%$, and $10 \%$ levels of significance. W-Test represents the Wald test, H-Test depicts the Hausman test, \{\} is for the probability values, and ( ) is for the standard errors.

\section{Source: Computed by authors, 2020}


Appendix 9: See Table 14

Table 14: Renewable Energy Consumption and Industrial Performance in LICs via Institutions

\begin{tabular}{|c|c|c|c|c|}
\hline \multirow{3}{*}{ DV: IP } & \multicolumn{4}{|c|}{ Random Effects (re) Models } \\
\hline & Model I & Model II & Model III & Model IV \\
\hline & & & & \\
\hline IQ & \multicolumn{4}{|l|}{$\begin{array}{l}0.3411 \\
(0.4851)\end{array}$} \\
\hline \multirow[t]{2}{*}{ REC } & $0.0129 *$ & 0.0169 & $0.0147 *$ & $0.0131 * *$ \\
\hline & $(0.0073)$ & $(0.0109)$ & $(0.0076)$ & $(0.0064)$ \\
\hline \multirow[t]{2}{*}{ FDI } & $0.0233 * * *$ & $0.0187 * * *$ & $0.0217 * * *$ & $0.0243 * * *$ \\
\hline & $(0.0054)$ & $(0.0041)$ & $(0.0047)$ & $(0.0065)$ \\
\hline \multirow[t]{2}{*}{ DCPS } & -0.0580 & -0.0760 & -0.0650 & -0.0569 \\
\hline & $(0.0946)$ & $(0.0930)$ & $(0.0948)$ & $(0.0942)$ \\
\hline \multirow[t]{2}{*}{ LPOP } & 1.4434 & $2.7701 *$ & 1.9064 & 1.2805 \\
\hline & $(3.0996)$ & $(1.6674)$ & $(2.6161)$ & $(3.1970)$ \\
\hline \multirow[t]{2}{*}{ INFR } & -0.0199 & -0.0157 & -0.0202 & -0.0239 \\
\hline & $(0.0996)$ & $(0.1041)$ & $(0.1010)$ & $(0.0965)$ \\
\hline \multirow[t]{2}{*}{ TO } & 0.0016 & 0.0005 & 0.0008 & 0.0017 \\
\hline & $(0.0088)$ & $(0.0078)$ & $(0.0097)$ & $(0.0094)$ \\
\hline \multirow[t]{2}{*}{$\mathrm{IQ}^{*} \mathrm{REC}$} & -0.0025 & & & \\
\hline & $(0.0057)$ & & & \\
\hline Const. & -5.554 & -26.31 & -12.785 & -3.009 \\
\hline Adj. $R^{2}$ & 0.871 & 0.646 & 0.828 & 0.874 \\
\hline W-Test & 91.33 & 76.4 & 87.49 & 101.69 \\
\hline$\{$ Prob. $\}$ & $\{0.000\}$ & $\{0.000\}$ & $\{0.000\}$ & $\{0.000\}$ \\
\hline H-Test & 4.06 & 12.03 & 6.05 & 3.97 \\
\hline$\{$ Prob. $\}$ & $\{0.668\}$ & $\{0.199\}$ & $\{0.417\}$ & $\{0.681\}$ \\
\hline
\end{tabular}

Notes: $* * *, * *$, and $*$ denote $1 \%, 5 \%$, and $10 \%$ levels of significance. W-Test represents the Wald test, H-Test depicts the Hausman test, \{\} is for the probability values, and ( ) is for the standard errors.

Source: Computed by authors, 2020 
Appendix 10: See Table 15

Table 15: Institution and Renewable Energy Consumption and Industrial Performance in West Africa (WA)

POLS FE RE

DV: IP

\begin{tabular}{|c|c|c|c|}
\hline \multirow[t]{2}{*}{ IQ } & $0.507 * * *$ & 0.221 & 0.293 \\
\hline & $(0.507)$ & $(0.325)$ & $(0.280)$ \\
\hline \multirow[t]{2}{*}{ REC } & -0.007 & 0.005 & 0.006 \\
\hline & $(0.014)$ & $(0.007)$ & (0.009) \\
\hline \multirow[t]{2}{*}{ FDI } & $-0.085^{* *}$ & $0.021 * *$ & $0.015 * *$ \\
\hline & $(0.033)$ & (0.008) & $(0.006)$ \\
\hline \multirow[t]{2}{*}{ DCPS } & $0.083 * *$ & -0.064 & -0.054 \\
\hline & $(0.036)$ & $(0.061)$ & $(0.049)$ \\
\hline \multirow[t]{2}{*}{ LPOP } & $2.446 * * *$ & 1.927 & $2.254 * *$ \\
\hline & $(0.278)$ & (4.148) & (1.058) \\
\hline \multirow[t]{2}{*}{ INFR } & $0.142 * *$ & -0.033 & -0.028 \\
\hline & $(0.056)$ & $(0.079)$ & $(0.080)$ \\
\hline \multirow[t]{2}{*}{ TO } & -0.017 & 0.006 & 0.005 \\
\hline & $(0.011)$ & $(0.011)$ & $(0.012)$ \\
\hline Const. & $-19.66 * * *$ & -11.056 & -16.372 \\
\hline Adj. $\mathrm{R}^{2}$ & 0.332 & 0.762 & 0.693 \\
\hline W-Test & & & 48.75 \\
\hline$\{$ Prob. $\}$ & & & $\{0.000\}$ \\
\hline F-Test & 21.13 & 10.22 & \\
\hline$\{$ Prob. $\}$ & $\{0.000\}$ & $\{0.000\}$ & \\
\hline
\end{tabular}

H-Test

11.58

\{Prob.\}

$\{0.115\}$

Notes: ***,**,and $*$ denote $1 \%, 5 \%$, and $10 \%$ levels of significance. W-Test represents the Wald test, H-Test depicts the Hausman test, \{\} is for the probability values, and ( ) is for the standard errors.

Source: Computed by authors, 2020 
Appendix 11: See Table 16

Table 16: Renewable Energy Consumption and Industrial Performance in West Africa via institutions

POLS FE RE

\begin{tabular}{|c|c|c|c|}
\hline \multicolumn{4}{|l|}{ DV: IP } \\
\hline \multirow[t]{2}{*}{ IQ } & $2.111 * * *$ & $1.186^{* * *}$ & $1.330 * * *$ \\
\hline & $(0.454)$ & $(0.429)$ & $(0.411)$ \\
\hline \multirow[t]{2}{*}{ REC } & -0.017 & -0.003 & -0.002 \\
\hline & $(0.014)$ & $(0.011)$ & (0.009) \\
\hline \multirow[t]{2}{*}{ FDI } & $-0.086 * * *$ & 0.021 & $0.016^{* *}$ \\
\hline & $(0.033)$ & $(0.021)$ & $(0.007)$ \\
\hline \multirow[t]{2}{*}{ DCPS } & 0.015 & $-0.080^{*}$ & -0.079 \\
\hline & (0.039) & $(0.044)$ & $(0.053)$ \\
\hline \multirow[t]{2}{*}{ LPOP } & $2.756 * * *$ & 1.888 & $2.451 * *$ \\
\hline & $(0.283)$ & (2.034) & (1.043) \\
\hline \multirow[t]{2}{*}{ INFR } & $0.099 *$ & -0.023 & -0.018 \\
\hline & $(0.056)$ & $(0.045)$ & $(0.078)$ \\
\hline \multirow[t]{2}{*}{ TO } & $-0.019 *$ & 0.006 & 0.005 \\
\hline & $(0.011)$ & (0.008) & $(0.011)$ \\
\hline \multirow[t]{2}{*}{ IQ*REC } & $-0.024 * * *$ & $-0.012^{* *}$ & $-0.013 * *$ \\
\hline & $(0.006)$ & $(0.004)$ & $(0.006)$ \\
\hline Const. & $-23.17 * * *$ & -10.017 & -18.98 \\
\hline Adj. $R^{2}$ & 0.364 & 0.75 & 0.729 \\
\hline W-Test & & & 59.74 \\
\hline$\{$ Prob. $\}$ & & & $\{0.000\}$ \\
\hline F-Test & 21.27 & 40.61 & \\
\hline$\{$ Prob. $\}$ & $\{0.000\}$ & $\{0.000\}$ & \\
\hline H-Test & & & 8.56 \\
\hline$\{$ Prob. $\}$ & & & $\{0.285\}$ \\
\hline
\end{tabular}

Notes: ***, **, and $*$ denote $1 \%, 5 \%$, and $10 \%$ levels of significance. W-Test represents the Wald test, H-Test depicts the Hausman test, \{\} is for the probability values, and ( ) is for the standard errors.

Source: Computed by authors, 2020 
Appendix 12: See Table 17

Table 17: Institutions, Renewable Energy Consumption and Industrial Performance in Lower-Middle-Income Countries in West Africa
POLS
FE
RE

DV: IP

\begin{tabular}{|c|c|c|c|}
\hline \multirow[t]{2}{*}{ IQ } & $0.508^{*}$ & $0.625^{* *}$ & $0.508^{*}$ \\
\hline & $(0.284)$ & $(0.258)$ & $(0.284)$ \\
\hline \multirow[t]{2}{*}{ REC } & $-0.033 * *$ & -0.002 & $-0.034 * *$ \\
\hline & $(0.017)$ & (0.013) & $(0.017)$ \\
\hline \multirow[t]{2}{*}{ FDI } & -0.112 & $-0.391 * *$ & -0.112 \\
\hline & $(0.157)$ & $(0.178)$ & $(0.157)$ \\
\hline \multirow[t]{2}{*}{ DCPS } & -0.044 & $-0.159 * * *$ & -0.044 \\
\hline & $(0.038)$ & $(0.047)$ & $(0.038)$ \\
\hline \multirow[t]{2}{*}{ LPOP } & $2.49 * * *$ & $14.49 * * *$ & $2.49 * * *$ \\
\hline & $(0.576)$ & $(4.061)$ & $(0.576)$ \\
\hline \multirow[t]{2}{*}{ INFR } & 0.004 & -0.066 & 0.005 \\
\hline & $(0.061)$ & $(0.114)$ & $(0.061)$ \\
\hline \multirow[t]{2}{*}{ TO } & $0.087 * * *$ & $0.132 * * *$ & $0.088^{* * *}$ \\
\hline & $(0.027)$ & $(0.032)$ & $(0.027)$ \\
\hline Const & $-21.099 *$ & $-218.91 * *$ & $-21.099 *$ \\
\hline Adj. $\mathrm{R}^{2}$ & 0.451 & 0.235 & 0.492 \\
\hline W.Test & & & 84.15 \\
\hline$\{$ Prob. $\}$ & & & $\{0.000\}$ \\
\hline F-Test & 12.02 & 6.74 & \\
\hline$\{$ Prob. $\}$ & $\{0.000\}$ & $\{0.000\}$ & \\
\hline H-Test & & & 14.18 \\
\hline$\{$ Prob. $\}$ & & & $\{0.048\}$ \\
\hline
\end{tabular}

Notes: ***,**, and * denote $1 \%, 5 \%$, and $10 \%$ levels of significance. W-Test represents the Wald test, H-Test depicts the Hausman test, \{\} is for the probability values, and ( ) is for the standard errors.

Source: Computed by authors, 2020 
Appendix 13: See Table 18

Table 18: Renewable Energy Consumption and Industrial Performance via Institutions in LMICs

POLS

FE

RE

DV: IP

IQ

$1.665 * * *$

$1.671^{* *}$

$1.665^{* * *}$

$(0.570)$

(0.699)

$(0.571)$

REC

$-0.05^{* * *}$

$-0.016$

$-0.05 * * *$

(0.017)

(0.021)

(0.017)

FDI

$-0.214$

$-0.422 * *$

$-0.214$

(0.160)

(0.171)

(0.160)

DCPS

$-0.086^{* *}$

$-0.179 * * *$

$-0.086^{* *}$

(0.041)

(0.061)

(0.041)

LPOP

2.476 ****

$13.594 * * *$

2.476 ***

(0.562)

(4.044)

(0.562)

INFR

0.016

$-0.015$

0.016

(0.060)

(0.089)

(0.060)

TO

0.084 ***

$0.111^{* * * *}$

$0.084 * * *$

(0.026)

(0.035)

(0.026)

IQ*REC

$-0.018^{* *}$

$-0.015^{*}$

$-0.018 * *$

(0.0070

(0.008)

(0.007)

Const.

$-19.223 *$

$-202.2 * * *$

$-19.223 *$

Adj. R $^{2}$

0.477

0.409

0.522

W-Test

93.79

\{Prob.\}

$\{0.000\}$

F-Test

11.72

\{Prob. $\}$

$\{0.000\}$

3.65

H-Test

$\{0.001\}$

11.83

\{Prob. $\}$

$\{0.159\}$

Notes: ***,**, and * denote $1 \%, 5 \%$, and $10 \%$ levels of significance. W-Test represents the Wald test, H-Test depicts the Hausman test, \{\} is for the probability values, and ( ) is for the standard errors.

Source: Computed by authors, 2020 
Appendix 14: See Table 19

Table 19: Institutions, Renewable Energy Consumption and Industrial Performance in LICs in West Africa

POLS FE RE

DV: IP

IQ

$\begin{array}{lll}-0.051 & 0.093 & 0.136\end{array}$

REC

(0.237)

(0.378)

(0.343)

0.003

0.009

0.0141 *

FDI

(0.0181)

(0.0075)

(0.0077)

$-0.067 *$

$0.027 * *$

$0.022 * * *$

(0.037)

(0.008)

(0.005)

DCPS

$-0.051$

$-0.033$

$-0.062$

(0.068)

(0.104)

(0.092)

LPOP

$3.782 * * *$

$-0.163$

1.805

(0.617)

(4.995)

(2.662)

INFR

$0.144 *$

$-0.019$

$-0.018$

(0.085)

(0.093)

(0.1004)

TO

$-0.033^{* *}$

0.003

0.0014

(0.013)

(0.009)

(0.0089)

Const.

$-39.53 * * *$

19.399

$-11.276$

Adj. R ${ }^{2}$

0.264

0.829

0.829

W.Test

66.07

\{Prob.

$\{0.000\}$

F-Test

10.65

11.71

\{Prob.

$\{0.000\}$

$\{0.000\}$

H-Test

\{Prob.

Notes: ***, **, and * denote $1 \%, 5 \%$, and $10 \%$ levels of significance. W-Test represents the Wald test, H-Test depicts the Hausman test, \{\} is for the probability values, and ( ) is for the standard errors.

Source: Computed by authors, 2020 
Appendix 15: See Table 20

Table 20: Renewable Energy Consumption and Industrial Performance in LICs via Institutions

\begin{tabular}{|c|c|c|c|}
\hline & POLS & $\mathrm{FE}$ & $\mathrm{RE}$ \\
\hline \multicolumn{4}{|l|}{ DV: IP } \\
\hline IQ & 0.437 & 0.305 & 0.341 \\
\hline Std Err & $(0.798)$ & $(0.501)$ & $(0.485)$ \\
\hline \multirow[t]{2}{*}{ REC } & 0.002 & 0.008 & $0.012^{*}$ \\
\hline & $(0.018)$ & $(0.007)$ & $(0.007)$ \\
\hline \multirow[t]{2}{*}{ FDI } & $-0.068^{*}$ & $0.027 * *$ & $0.023^{* * * *}$ \\
\hline & $(0.037)$ & $(0.008)$ & $(0.005)$ \\
\hline \multirow[t]{2}{*}{ DCPS } & -0.051 & -0.034 & -0.058 \\
\hline & $(0.068)$ & (0.104) & $(0.094)$ \\
\hline \multirow[t]{2}{*}{ LPOP } & $3.814 * * *$ & -0.1805 & 1.443 \\
\hline & $(0.620)$ & $(5.051)$ & (3.099) \\
\hline \multirow[t]{2}{*}{ INFR } & $0.144 *$ & -0.021 & -0.019 \\
\hline & $(0.086)$ & (0.094) & (0.099) \\
\hline \multirow[t]{2}{*}{ TO } & $-0.033 * *$ & 0.002 & 0.001 \\
\hline & $(0.013)$ & (0.008) & (0.008) \\
\hline \multirow[t]{2}{*}{ IQ*REC } & -0.006 & -0.002 & -0.002 \\
\hline & $(0.010)$ & $(0.005)$ & \\
\hline Const. & $-40.07^{* * *}$ & 19.748 & -5.554 \\
\hline Adj. $R^{2}$ & 0.262 & 0.828 & 0.871 \\
\hline W-Test & & & 91.33 \\
\hline$\{$ Prob. $\}$ & & & $\{0.000\}$ \\
\hline F-Test & 9.34 & 9.63 & \\
\hline$\{$ Prob. $\}$ & $\{0.000\}$ & $\{0.001\}$ & \\
\hline H-Test & & & 4.06 \\
\hline$\{$ Prob. $\}$ & 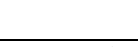 & 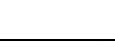 & $\{0.668\}$ \\
\hline
\end{tabular}

Source: Computed by authors, 2020 


\section{Supplementary Files}

This is a list of supplementary files associated with this preprint. Click to download.

- Project2Do.do 